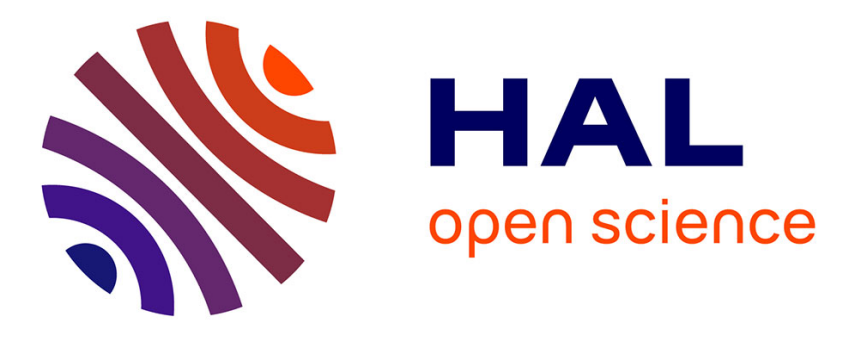

\title{
Reversible redox switching of chromophoric phenylmethylenepyrans by carbon-carbon bond making/breaking
}

Laurianne Wojcik, François Michaud, Sebastien Gauthier, Nolwenn Cabon, Pascal Le Poul, Frederic Gloaguen, Nicolas Le Poul

\section{To cite this version:}

Laurianne Wojcik, François Michaud, Sebastien Gauthier, Nolwenn Cabon, Pascal Le Poul, et al.. Reversible redox switching of chromophoric phenylmethylenepyrans by carbon-carbon bond making/breaking. Journal of Organic Chemistry, 2017, 82 (23), pp.12395 - 12405. 10.1021/acs.joc.7b02199 . hal-01624342

\section{HAL Id: hal-01624342 \\ https://hal.univ-brest.fr/hal-01624342}

Submitted on 10 Jan 2018

HAL is a multi-disciplinary open access archive for the deposit and dissemination of scientific research documents, whether they are published or not. The documents may come from teaching and research institutions in France or abroad, or from public or private research centers.
L'archive ouverte pluridisciplinaire HAL, est destinée au dépôt et à la diffusion de documents scientifiques de niveau recherche, publiés ou non, émanant des établissements d'enseignement et de recherche français ou étrangers, des laboratoires publics ou privés. 


\title{
Reversible redox switching of chromophoric
}

\section{phenylmethylenepyrans by carbon-carbon bond}

\section{making/breaking}

\author{
Laurianne Wojcik, ${ }^{\mathrm{a}}$ François Michaud, ${ }^{\mathrm{b}}$ Sébastien Gauthier, ${ }^{\mathrm{c}}$ Nolwenn Cabon, ${ }^{\mathrm{c}}$
} Pascal Le Poul, ${ }^{\mathrm{c}}$ Frederic Gloaguen, ${ }^{\mathrm{a}}$ Nicolas Le Poul ${ }^{\mathrm{a}, *}$

${ }^{a}$ Laboratoire CEMCA, CNRS UMR 6521, Université de Bretagne Occidentale, 6 Avenue Le Gorgeu, CS 93837, 29238 Brest Cedex, France.

${ }^{b}$ Service PIMM-DRX, Université de Bretagne Occidentale, 6 Avenue Le Gorgeu, CS 93837, 29238 Brest Cedex, France.

${ }^{c}$ IUT de Lannion, CNRS UMR 6226, Institut des Sciences Chimiques de Rennes, Université de Rennes 1, Rue Edouard Branly, 22300 Lannion, France.

Keywords : redox switch; radical dimerization; spectroelectrochemistry; bistability; pyran

\begin{abstract}
Electrochromic organic systems that can undergo substantial variation of their optical properties upon electron stimulus are of high interest for the development of functional materials. In particular, devices based on radical dimerization are appropriate because of the effectiveness and speed of the carbon-carbon bond making/breaking. Phenylmethylenepyrans are organic chromophores which are well suited for such purpose since their oxidation leads to the reversible formation of bispyrylium species by radical dimerization. In this paper, we show that the redox and spectroscopic properties of phenylmethylenepyrans can be modulated by adequate variation of the substituting group on the para position of the phenyl moiety, as supported by DFT calculations. This redox switching is reversible over several cycles and is accompanied by a significant modification of the UV-Vis spectrum of the chromophore, as shown by time-resolved spectroelectrochemistry in thin layer conditions.
\end{abstract}




\section{Introduction}

Molecular switches are compounds that can undergo reversible structural changes upon application of an external stimuli, such as light, heat, electrons or chemical reactions. Switches displaying optical and redox properties are particularly prone to lead to smart materials in the field of electrochromic and memory devices. ${ }^{1,2}$ Different strategies have been used to target efficient devices depending on the intra- or intermolecular character of the reactions and their associated kinetics. Supramolecular approaches involving large amplitude motion of their inner components, such as observed in mechanically interlocked molecular (MIM) switches, have been widely developed over the past years, leading to a wide range of functionalized systems including coordination metal complexes and purely organic systems. ${ }^{3-10}$ Alternatively, organic chromophores displaying low-amplitude motion have also drawn interest when fast switching time is requested. Devices based on the photoactivatedswitching between two isomers, such as azobenzenes, have been well developed over the past years. ${ }^{11,12}$ Redoxtriggered switches displaying reversible $\pi$ - or $\sigma$-dimerization from electrochemically or photochemically generated radical anions or cations have also drawn interest. ${ }^{13-19,}$ In particular, intermolecular $\sigma_{\mathrm{C}-\mathrm{C}}$ dimerization of radical cations of conjugated aromatic systems, such as stilbene, ${ }^{20}$ triarylamines,${ }^{21,22}$ pyridine, ${ }^{23}$ cyanins, ${ }^{24}$ dialkoxyanthracene, ${ }^{25}$ spiropyran $^{26,27}$ tripyrrolinidobenzene ${ }^{28}$, bis(benzo-dithiolyl)bithienyl ${ }^{29}$ and dithiafulvene ${ }^{30-}$ ${ }^{32}$ were reported. Noteworthy, recent investigations have focused on the immobilization of this family of redox switches on solid surfaces for the development of smart multiple responsive materials. ${ }^{26,33-35}$

$\gamma$-methylenepyran compounds are organic chromophores which have been recently integrated as donors in push-pull devices for applications in non-linear optics and photovoltaic cells. ${ }^{36-39}$ Interestingly, electrochemical studies have shown that methylenepyran compounds can undergo fast dimerization by $\sigma_{\mathrm{C}-\mathrm{C}}$ bond making upon oxidation at moderate potential values $\left(E_{\mathrm{p}} \sim 0.3 \mathrm{~V}\right.$ vs. Fc) in organic solvents. ${ }^{37,38,40,41}$ The resulting bispyrylium species is reduced irreversibly around $-0.8 \mathrm{~V}$ vs. Fc leading back to the initial methylenepyran by $\mathrm{C}-\mathrm{C}$ bond breaking (Scheme 1). ${ }^{40-43}$ Bispyrylium compounds are much less sensitive to self-deprotonation than their bisdithiolium analogues. ${ }^{30,40,43}$ Such stability is of high importance when considering prospective application in the field of organic redox switches. Moreover, another aspect of interest of this family of compounds is their optical properties associated to their conjugated structure. Indeed, most of these dyes display intense absorption bands in the 350-700 $\mathrm{nm}$ wavelength range, depending on the degree of conjugation, in addition to the fluorescence properties. ${ }^{37-39}$ To our knowledge, there has been no report on the use of the redox and optical properties of this family of compounds for redox-triggered molecular switching. 
Herein, we have focused on the switching properties of different para-substituted phenylmethylenepyrans $\left({ }^{R} \mathrm{PhMP}\right.$, Scheme 1) as probed by spectroelectrochemistry. In order to minimize geometric distortion of the structure by hindering groups, substitution was carried out on the phenyl group rather than on the ethylene moiety. Indeed, the optical and redox properties of the neutral and oxidized forms of ${ }^{\mathrm{R}} \mathrm{PhMP}$ can be more easily controlled by simple variation of the substituent R. Electrochemical and UV-Vis spectroscopic studies, supported by DFT and TD-DFT calculations, were thus performed to investigate the effect of the substituting group on the redox and optical properties. In addition, spectroelectrochemical experiments were carried out to characterize the switching properties of this series of compounds by variation of the applied potential.

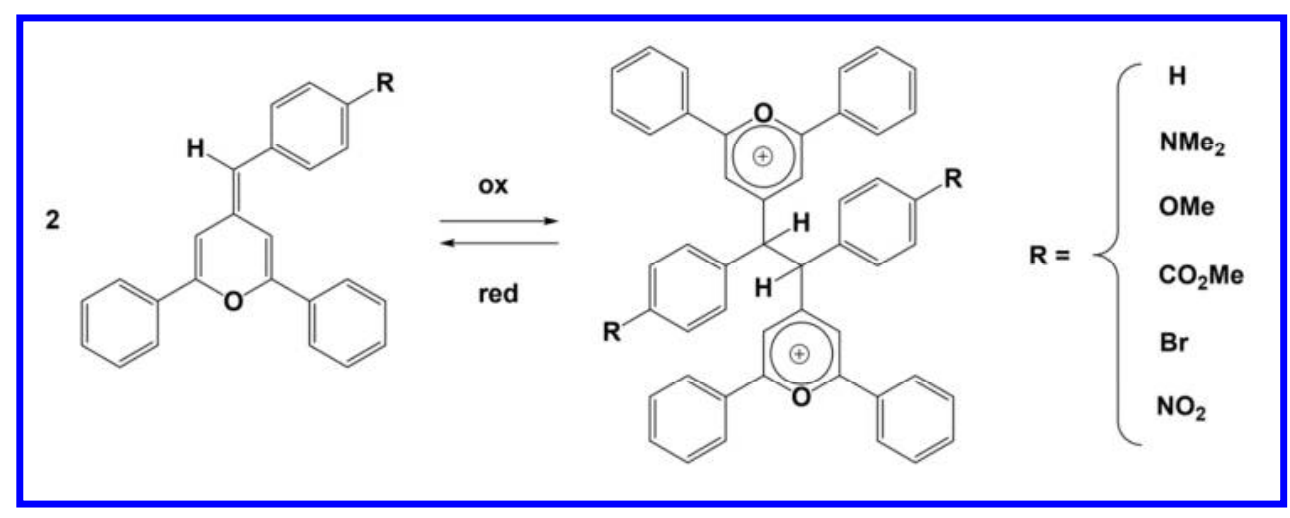

Scheme 1. Reversible $\mathrm{C}-\mathrm{C}$ bond making/breaking by electrochemical oxidation of R-substituted phenylmethylenepyrans $\left({ }^{\mathrm{R}} \mathrm{PhMP}\right)$ and reduction of their bispyrylium derivatives.

\section{Results and discussion}

\section{Synthesis of compounds $2 \mathrm{a}-\mathrm{f}$}

Syntheses of $\mathbf{2} \mathbf{a}^{44,45}, \mathbf{2} \mathbf{c}^{44,45}, \mathbf{2} \mathbf{d}{ }^{41}$ and $\mathbf{2} \mathbf{e}^{46}$ were performed as previously reported. The synthesis is based on a Wittig-type reaction between the 2,6-diphenyl-4H-pyran-4-yl triphenyl $\left(\mathbf{1}^{\mathbf{P h}}\right)$ phosphonium tetrafluoroborate salt and the substituted formylbenzoate ${ }^{\mathrm{R}} \mathrm{PhCHO}$ (Scheme 2). For the newly prepared compounds $\mathbf{2 b}$ and $\mathbf{2} \mathbf{f}$, a more convenient procedure was carried out using a tributyl $\left(\mathbf{1}^{\mathbf{n}-\mathrm{Bu}}\right)$ pyranyl derivative instead of a triphenyl one $\left(\mathbf{1}^{\mathrm{Ph}}\right)$. All compounds were characterized by ${ }^{1} \mathrm{H}$ and ${ }^{13} \mathrm{C}$ NMR spectroscopy, and mass spectrometry (see SI part). 

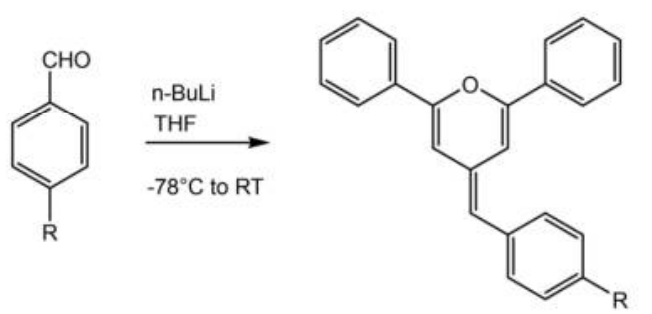

$1^{\mathrm{Ph}} \quad \mathrm{X}=\mathrm{Ph}$

$1^{n-B u} \quad X=n-B u$

$$
\begin{array}{ll}
\text { 2a } & \mathrm{R}=\mathrm{H} \\
\text { 2b } & \mathrm{R}=\mathrm{NMe}_{2} \\
\text { 2c } & \mathrm{R}=\mathrm{OMe} \\
\text { 2d } & \mathrm{R}=\mathrm{CO}_{2} \mathrm{Me} \\
\text { 2e } & \mathrm{R}=\mathrm{Br} \\
\text { 2f } & \mathrm{R}=\mathrm{NO}_{2}
\end{array}
$$

Scheme 2. Schematic pathway for the syntheses of R-substituted phenylmethylenepyran compounds 2 a-f.

\section{Synthesis of compounds $3 \mathrm{f}^{2+}$ and $4 \mathrm{f}$}

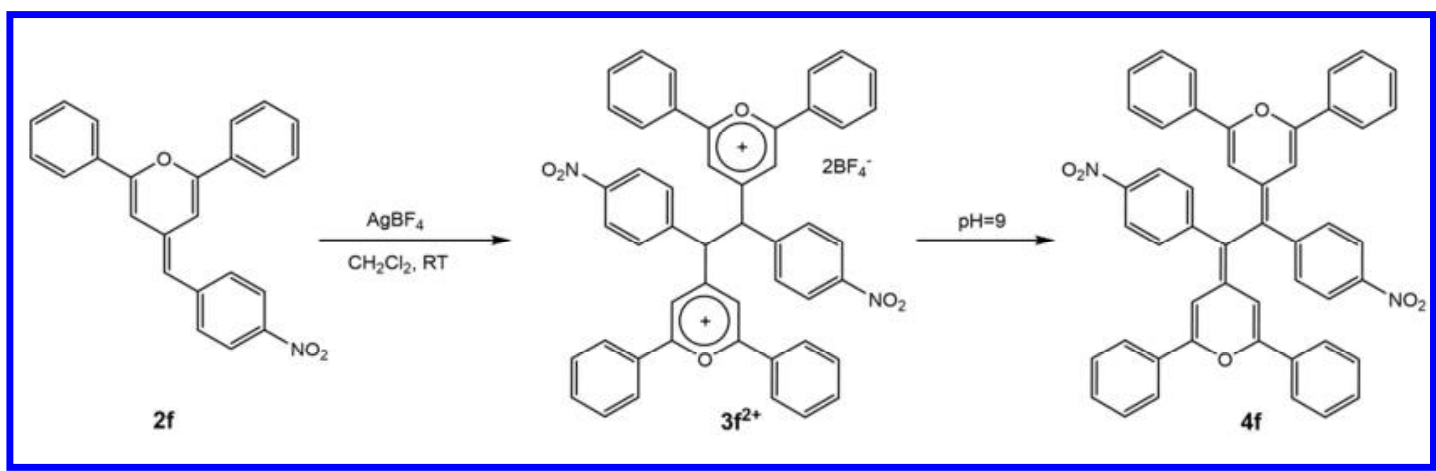

Scheme 3. Schematic pathway for the synthesis of compound $\mathbf{3 f ^ { 2 + }}$ and $\mathbf{4 f}$.

The two-step synthesis of the bispyran compound $\mathbf{4 f}$ was undertaken following a previously-described procedure (Scheme 3). ${ }^{47}$ During the first step, addition of the oxidizing agent $\mathrm{AgBF}_{4}$ to a solution of $\mathbf{2} \mathbf{f}$ in $\mathrm{CH}_{2} \mathrm{Cl}_{2}$ led to the formation of a bispyrylium derivative $\mathbf{3 f}^{2+}$. Compound $\mathbf{3 f ^ { 2 + }}$ was isolated and characterized by ${ }^{1} \mathrm{H}$ NMR, ${ }^{13} \mathrm{C}$ NMR, mass spectrometry and cyclic voltammetry (see Experimental Section and SI part). On the ${ }^{1} \mathrm{H}$ NMR spectrum of $\mathbf{3 f}^{\mathbf{2 +}}$, two diastereoisomers were observed in a 30/70 ratio. Then, a large excess of $\mathrm{pH} 9$ solution (glycine buffer) was added to a solution of $\mathbf{3} \mathbf{f}^{2+}$ in $\mathrm{CH}_{2} \mathrm{Cl}_{2}$ and the two-phases mixture was stirred for half an hour at room temperature. At this stage, the deprotonation of the bispyrylium compound occurred and the bispyran derivative $4 \mathbf{f}$ was formed. Compound $\mathbf{4 f}$ was isolated and characterized by ${ }^{1} \mathrm{H} N M R,{ }^{13} \mathrm{C}$ NMR, mass spectrometry and cyclic voltammetry (see Experimental Section and SI part). The ${ }^{1} \mathrm{H}$ NMR spectrum of $\mathbf{4 f}$ displayed characteristic signals for the two non-equivalent heterocyclic hydrogen atoms at $6.56 \mathrm{ppm}$ and 6.98 
ppm. The lack of signal for the exocyclic hydrogen atom of the pyranylidene moiety, which was observed at 5.97 ppm for $\mathbf{2 f}$, confirmed also the proposed structure.

\section{$\underline{\text { Structural characterisation of }}{ }^{\mathrm{NMe} 2} \mathrm{PhMP}(2 \mathrm{~b})$}

The molecular structure of compound $\mathbf{2 b}$ is displayed in Figure 1. The phenylmethylenepyran compound crystallizes in the monoclinic centrosymmetric space group C2/c (Table S1). Selected bond distances and angles are gathered in Table 1. C-C bonds lengths lie in the range of 1.374(3) to 1.390(3) $\AA$ for the three phenyl rings. Low variation of the bond lengths are observed $(<0.03 \AA)$, thus indicating that electron density is uniformly delocalized in these parts of the molecule. The pyran ring displays less homogeneity between lengths since C7-C8 (1.343(3) $\AA)$ and C10-C11 bonds (1.335(3) $\AA$ ) are significantly shorter than C8-C9 (1.452(2) $\AA)$ and

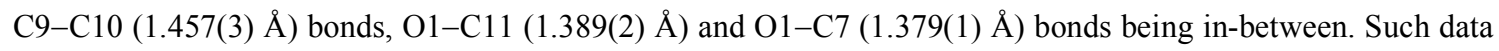
corroborate alternating single and double carbon-carbon bonds in the pyran ring. The exocyclic C9-C18 bond length is $1.362(3) \AA$, which suggests a weak pyrylium character. ${ }^{43}$ Comparison with the analogous methylenepyran $\mathbf{2 d}$ bearing a carboxy substituting group ${ }^{41}$ is shown in Table 1. Clearly, both compounds display similar bond lengths and angles. The R-substituted phenyl ring and the pyran moiety are not co-planar for both compounds $\mathbf{2 b}$ and $\mathbf{2 d}$. This is best emphasized by the torsion angle between C24-C19-C18-C9 which are similar for both compounds $\left(151.49^{\circ}\right.$ for $\mathbf{2 b}$ and $149.88^{\circ}$ for $\left.\mathbf{2 d}\right)$.

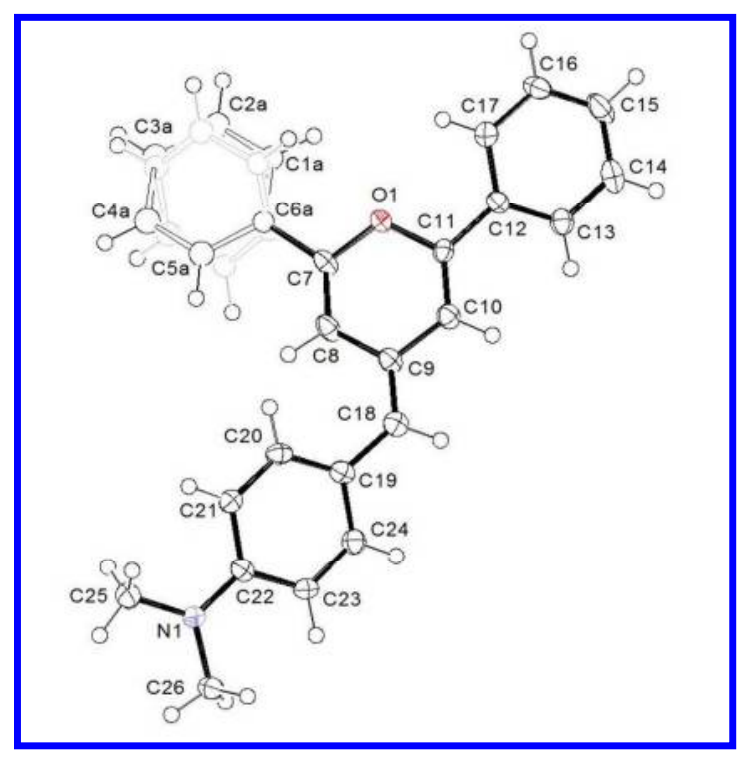

Figure 1. Molecular structure of ${ }^{\mathrm{NMe} 2} \mathrm{PhMP}(\mathbf{2 b})$ with the atom numbering scheme. Thermal ellipsoids are drawn at 50\% probability. One phenyl group is modelled as split into two positions (high thermal motion). 
Table 1. Selected bond distances $(\AA)$ and angles $\left({ }^{\circ}\right)$ for ${ }^{\mathrm{R}} \mathrm{PhMP}$ compounds $\left(\mathrm{R}=\mathrm{NMe}_{2} \mathbf{2 b}\right.$ and $\left.\mathrm{R}=\mathrm{CO}_{2} \mathrm{Me} \mathbf{2 d}{ }^{41}\right)$ according to numbering in Figure 1.

\begin{tabular}{lll}
\hline & $\mathrm{R}=\mathrm{NMe}_{2}(\mathbf{2 b})$ & $\mathrm{R}=\mathrm{CO}_{2} \mathrm{Me}(\mathbf{2 d})$ \\
\hline $\mathrm{C} 7-\mathrm{O} 1$ & $1.379(2)$ & $1.377(8)$ \\
$\mathrm{C} 9-\mathrm{C} 18$ & $1.362(3)$ & $1.370(10)$ \\
$\mathrm{C} 11-\mathrm{C} 12$ & $1.472(2)$ & $1.483(9)$ \\
$\mathrm{C} 11-\mathrm{O} 1$ & $1.389(2)$ & $1.376(8)$ \\
$\mathrm{C} 18-\mathrm{C} 19$ & $1.466(3)$ & $1.441(1)$ \\
$\mathrm{C} 22-\mathrm{R}$ & $1.381(2)$ & $1.479(1)$ \\
$\mathrm{C} 9-\mathrm{C} 18-\mathrm{C} 19$ & $128.4(2)$ & $127.6(4)$ \\
$\mathrm{C} 8-\mathrm{C} 9-\mathrm{C} 18$ & $125.4(2)$ & $126.8(0)$ \\
$\mathrm{C} 10-\mathrm{C} 9-\mathrm{C} 18$ & $122.1(2)$ & $120.1(7)$ \\
\hline
\end{tabular}

\section{$\underline{\text { Electrochemical and computational studies }}$}

Cyclic voltammetric (CV) study of compounds 2a-f was performed at a Pt working electrode $(0.3 \mathrm{~cm}$ in diameter) in dry $\mathrm{N}_{2}$-purged $\mathrm{CH}_{2} \mathrm{Cl}_{2}$ containing $0.1 \mathrm{M} \mathrm{NBu}_{4} \mathrm{PF}_{6}$ as supporting electrolyte. Electrochemical data are gathered in Table 2. As shown in Figure 2A, all ${ }^{\mathrm{R}} \mathrm{PhMP}$ compounds displayed a similar redox behavior, i.e. a single irreversible anodic peak $\left(-0.18 \mathrm{~V}<E_{\mathrm{pa}}<0.41 \mathrm{~V}\right.$ vs. Fc at $\left.v=0.1 \mathrm{~V} \mathrm{~s}^{-1}\right)$ on the forward scan and an irreversible cathodic peak on the backward scan $\left(-0.86 \mathrm{~V}<E_{\mathrm{pc}}<0.70 \mathrm{~V}\right.$ vs. Fc $)$. Variation of the scan rate $(0.02$ $\mathrm{V} \mathrm{s}^{-1}<v<5 \mathrm{~V} \mathrm{~s}^{-1}$ ) did not modify the redox behavior (Figure 2C). However, for $v>20 \mathrm{~V} \mathrm{~s}^{-1}$, the oxidation process became quasi-reversible (Figure S2). Voltammograms recorded at more negative potential did not display any new redox signal except for the $\mathrm{NO}_{2}$ derivative $2 \mathbf{f}\left(E_{1 / 2}=-1.90 \mathrm{~V}\right.$ vs. $\mathrm{Fc}, \Delta E_{\mathrm{p}}=80 \mathrm{mV}$, not shown). For all species, the process at $E_{\mathrm{pc}}$ was no longer detected when scanning negatively on the forward scan or on voltammograms recorded at a rotating disk electrode ( $R D E$, see inset Figure $2 \mathrm{D}$, curve a for $\mathrm{R}=\mathrm{H}$ ). Exhaustive electrolysis of solutions of ${ }^{\mathrm{R}} \mathrm{PhMP}$ at $E_{\mathrm{pa}}\left(n=1 \mathrm{e}^{-}\right)$confirmed the stability of the resulting species reduced at $E_{\mathrm{pc}}$ $\sim-0.8 \mathrm{~V}$ (Figure 2D). Irreversibility of the oxidative process emphasized the occurrence of an EC mechanism (E = Electrochemical step, $\mathrm{C}=$ Chemical step), for which the $\mathrm{C}$ step corresponds to the coupling of a radical cation either with another radical cation (RRD mechanism) or with a neutral ${ }^{\mathrm{R}} \mathrm{PhMP}$ species (RSD mechanism). ${ }^{48,49}$

On the basis of previous studies with analogous methylenepyrans, ${ }^{40,42,43}$ the irreversible reduction process at ca. $E_{\mathrm{pc}} \sim-0.8 \mathrm{~V}$ can be ascribed to the reduction of the electrogenerated bispyrylium species [3a-f $\mathbf{f}^{2+}$ (see Figure 
S7 for the $\mathrm{CV}$ of $\mathbf{3 f}^{2+}$ ). As shown in Scheme 4, the whole process corresponds to a $\mathrm{C}-\mathrm{C}$ bond making (oxidation)/breaking (reduction) involving two phenylmethylenepyran units as previously observed with ferrocenyl-based methylenepyrans. ${ }^{40}$ In order to correlate the redox behavior of 2a-f with the donor properties of the R group, $E_{\mathrm{pa}}$ values were plotted against the corresponding Brown coefficients $\sigma^{+}$. As shown in Figure 2B, plots follow a linear trend meaning that electronic effects of the R-phenyl group essentially govern the oxidation process. Conversely, the reduction potential of the bispyrylium $3^{2+}$ is almost independent of the nature of $\mathrm{R}$ (Figure 2A).
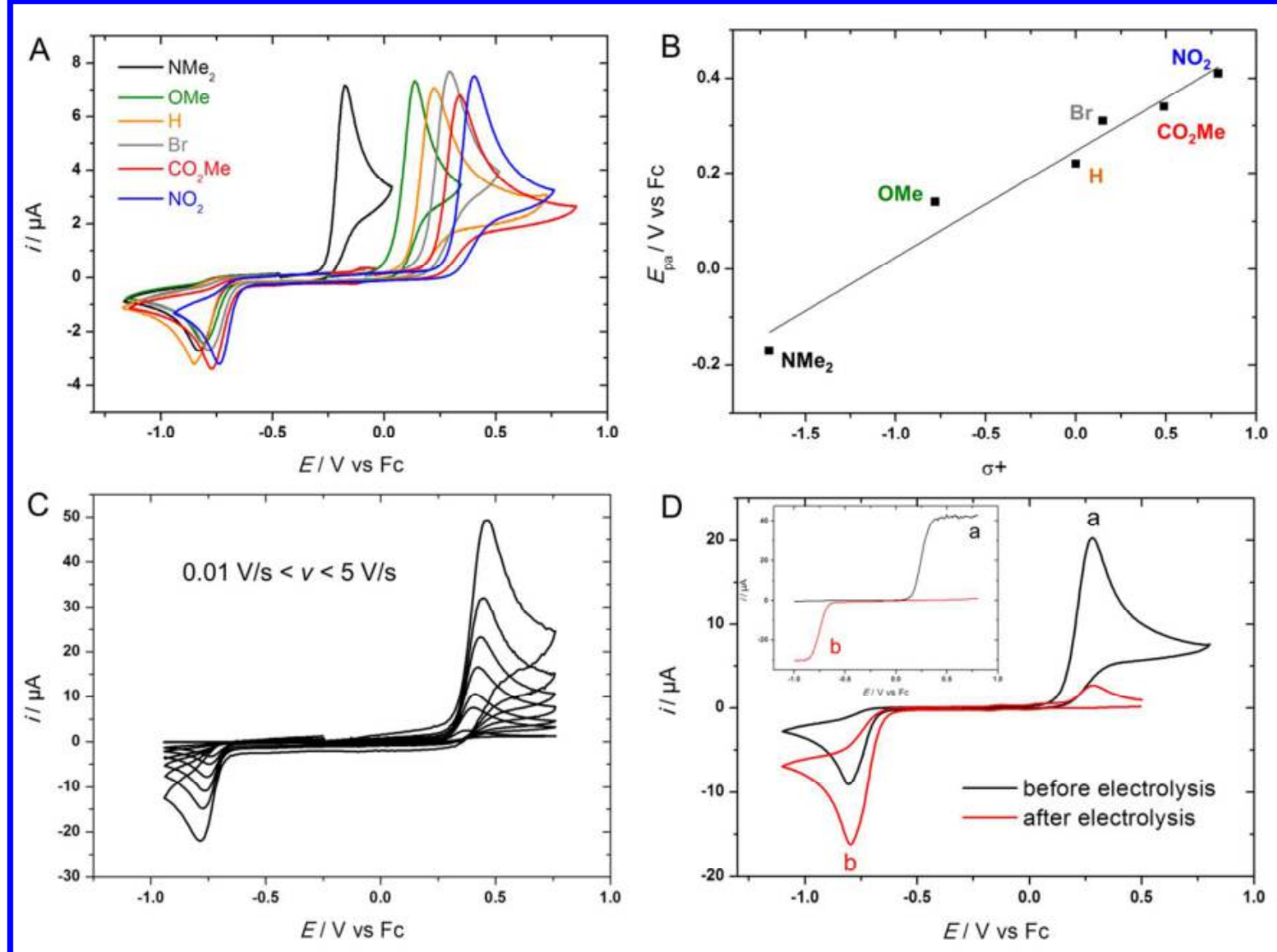

Figure 2. A) CVs at a Pt electrode of R-substituted phenylmethylenepyran compounds ${ }^{\mathrm{R}} \mathrm{PhMP}$ 2a-f $(0.50 \mathrm{mM})$ in $\mathrm{CH}_{2} \mathrm{Cl}_{2} / \mathrm{NBu}_{4} \mathrm{PF}_{6} 0.1 \mathrm{M}: v=0.1 \mathrm{~V} \mathrm{~s}^{-1} ; \mathrm{R}=\mathrm{NO}_{2}$ (blue), $\mathrm{CO}_{2} \mathrm{Me}$ (red), $\mathrm{Br}$ (gray), $\mathrm{H}$ (orange), $\mathrm{OMe}$ (green), $\mathrm{NMe}_{2}$ (black); B) Corresponding plots of $E_{\mathrm{pa}}$ vs. Brown constant $\sigma^{+}$; C) $\mathrm{CVs}$ of ${ }^{\mathrm{NO} 2} \mathrm{PhMP} \mathbf{2 f}(\mathrm{C}=0.50 \mathrm{mM})$ for $0.01 \mathrm{~V}$ $\mathrm{s}^{-1}<v<5 \mathrm{~V} \mathrm{~s}^{-1}$; D) CVs and RDEVs (inset) of ${ }^{\mathrm{H}} \mathrm{PhMP} 2 \mathrm{a}(\mathrm{C}=1.1 \mathrm{mM})$ before (black, a) and after (red, b) exhaustive electrolysis at $0.4 \mathrm{~V}$. 

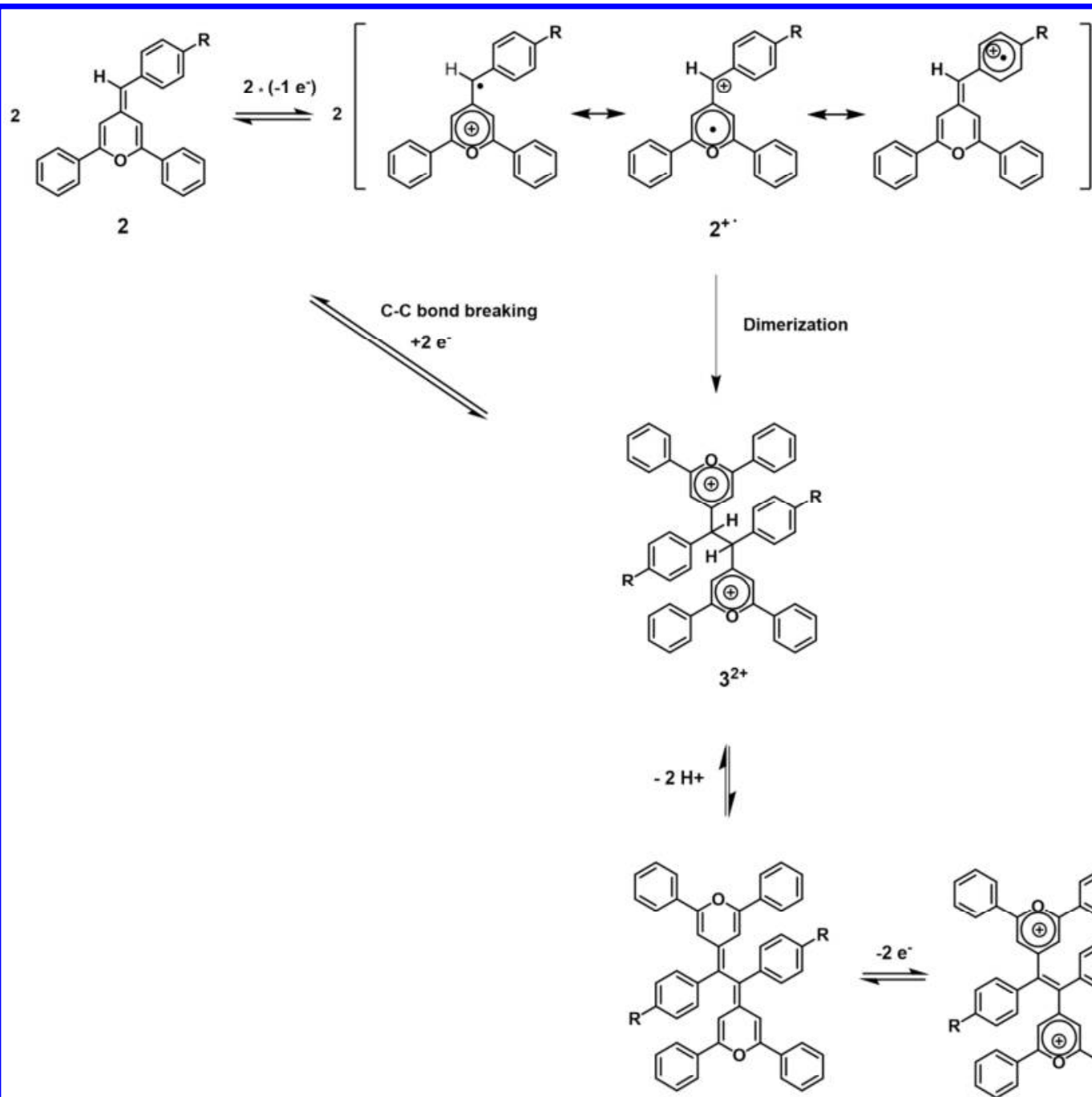

4
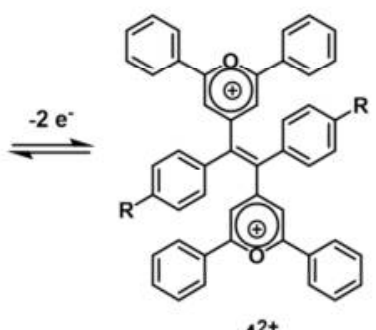

Scheme 4. Schematic pathways for the $\mathrm{C}-\mathrm{C}$ bond making/breaking of R-substituted phenylmethylenepyran

${ }^{\mathrm{R}} \mathrm{PhMP}$ compounds upon electron/proton transfer. 
Table 2. Electrochemical data for compounds 2a-f in $\mathrm{CH}_{2} \mathrm{Cl}_{2} / \mathrm{NBu}_{4} \mathrm{PF}_{6} 0.1 \mathrm{M}$.

\begin{tabular}{|c|c|c|c|c|}
\hline & $\mathbf{R}$ & $\boldsymbol{E}_{\mathrm{pa}}^{\mathrm{a}, \mathrm{b}}$ & $\boldsymbol{E}_{\mathrm{pc}}^{\mathrm{a}, \mathrm{b}, \mathrm{c}}$ & $\boldsymbol{E}^{0}{ }_{\text {(theor., ox.) }}{ }^{\mathrm{d}}$ \\
\hline $2 a$ & $\mathrm{H}$ & 0.22 & -0.85 & 0.32 \\
\hline $2 b$ & $\mathrm{NMe}_{2}$ & -0.17 & -0.83 & -0.15 \\
\hline $2 c$ & $\mathrm{OMe}$ & 0.14 & -0.81 & 0.15 \\
\hline $2 d$ & $\mathrm{CO}_{2} \mathrm{Me}$ & 0.34 & -0.77 & 0.44 \\
\hline $2 e$ & $\mathrm{Br}$ & 0.29 & -0.78 & 0.38 \\
\hline $2 f$ & $\mathrm{NO}_{2}$ & 0.41 & -0.73 & 0.60 \\
\hline
\end{tabular}

Computational analysis was carried out in order to correlate structural features and redox properties for the entire series of compounds $\mathbf{2 a - f}$. First calculations were performed with compounds $\mathbf{2 b}$ and $\mathbf{2 d}$ for comparison with X-ray structures (see SI for computational details). Bond distances and angles found from computed gasphase structures at the B3LYP/6-31+G(d,p) level are in good agreement with experimental data (Table S2). These results indicated that the calculation level was sufficiently accurate for allowing further analysis of the whole ${ }^{\mathrm{R}} \mathrm{PhMP}$ series. Hence, geometries of all compounds $\mathbf{2 a - f}$ were optimized in gas phase. Close inspection of the structural properties demonstrated that distances and angles do not vary in a significant manner with R (Table S3). Schematic representations of the charge density at the HOMO level for $\mathbf{2 b}\left(\mathrm{R}=\mathrm{NMe}_{2}\right)$ and $\mathbf{2} \mathbf{f}\left(\mathrm{R}=\mathrm{NO}_{2}\right)$ are shown in Figure 3 (See Figure S18 for 2a, 2c, 2d, 2e). For all the compounds, electron density is mainly localized on both the substituted phenyl and the pyran ring. 

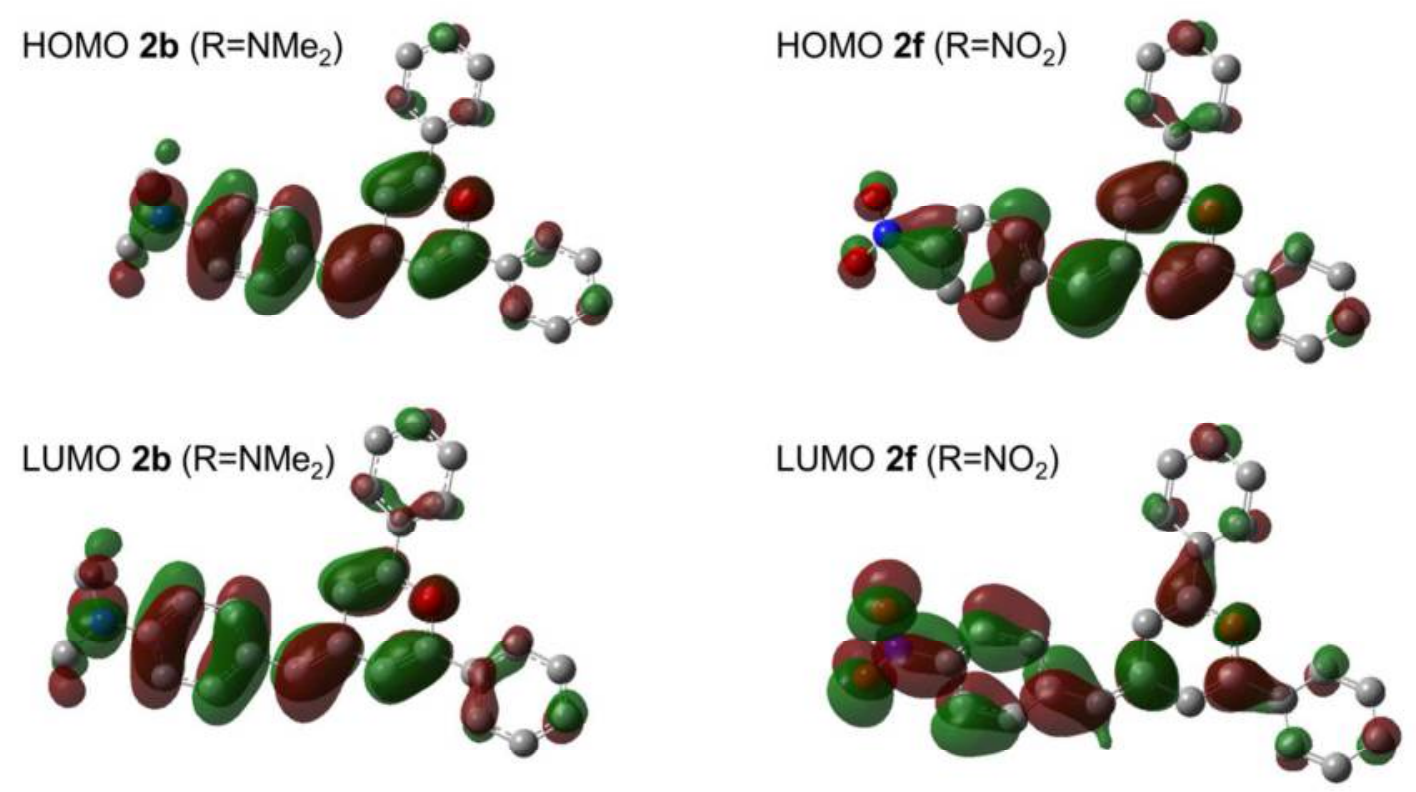

SOMO $2 b^{+}\left(R=\mathrm{NMe}_{2}\right)$

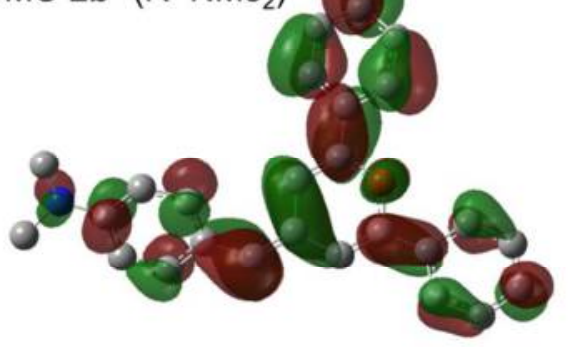

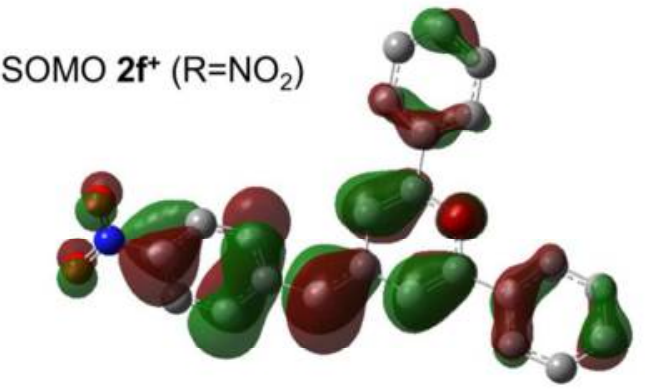

Figure 3. Isodensity surfaces (isovalue of 0.02 ) of the HOMO and the LUMO of $\mathbf{2 b}$ and $\mathbf{2 f}$, and of the SOMO of $\mathbf{2 b}^{+}$and $\mathbf{2 \mathbf { f } ^ { + }}$ at the B3LYP/6-31+G(d,p) level of theory.

Further analysis was performed on the calculated structures of the radical cations $\mathbf{2 a - \mathbf { f } ^ { + }}$ in gas phase, these species being too unstable to be isolated or characterized by spectroelectrochemistry. Modification of the C-C, C-O and C-N bond lengths upon electron withdrawing was particularly investigated (Table S4, Figure S22). Several conclusions can be drawn for this family of compounds, independently of the nature of the R substituting group. The main effects of oxidation on the structure is an increase by ca. $0.048 \AA$ of the acyclic C9-C18 bond close to the pyran moiety along with a decrease by ca. $0.035 \AA$ of the adjacent C18-C19 bond. Consequently, these bonds have a similar length value of ca. $1.42 \AA$ suggesting equal charge delocalization. The structure of the pyran moiety is also affected by the oxidation in a similar manner (i.e. an increase of the double bonds C10-C11 and $\mathrm{C} 7-\mathrm{C} 8$ along with a decrease of the single bonds $\mathrm{C} 8-\mathrm{C} 9, \mathrm{C} 9-\mathrm{C} 10, \mathrm{C} 11-\mathrm{O} 1, \mathrm{C} 7-\mathrm{O} 1)$. The structure of both unsubstituted phenyl groups attached to the pyran moiety are unaffected by the oxidation. Moreover, the length 
of the C-C bonds in the R-substituted phenyl group is not significantly modified. However, the C22-R bond increases or decreases significantly depending on the nature of R (i.e. by $0.03 \AA$ for $\mathrm{R}=\mathrm{NMe}_{2}$ and $\mathrm{OMe}$ ). Formation of the monopyrylium $\mathbf{2}^{+\bullet}$ cation is also accompanied by minor changes in the angles. As depicted in Figure S22 for 2e, the C1-C6 phenyl group is slightly twisted out of plane of the pyran moiety by $3^{\circ}$. Also, the pyran group is twisted towards the plane of the R-substituted group by $7^{\circ}$ (from $26^{\circ}$ to $33^{\circ}$ ) upon oxidation, in agreement with charge delocalization. Isodensity surfaces of the SOMO of the radical cations $\mathbf{2 b}^{+}$and $\mathbf{2 f}^{+}$are shown in Figure 3. Interestingly, the localization of the electron density is fully R-dependent for these two cations. Electron density of the SOMO of $\mathbf{2 f}^{+}$is mainly localized on the R-substituted phenyl and the pyran moieties. In contrast, it is positioned on the unsubstituted phenyl ring and the pyran moieties for the cations $\mathbf{2} \mathbf{b}^{+}$. This result emphasizes that the R-dependent variation of the redox potential of these two cations is likely associated to the stabilization effect of the R-substituting group on the radical cation. Further analysis of the spin density clearly shows that for the cation $\mathbf{2 f}^{+}\left(\mathrm{R}=\mathrm{NO}_{2}\right)$ the positive charge is strongly localized on $\mathrm{C} 18$, i.e. where dimerization occurs (Figure S29). In contrast, for the cation $\mathbf{2 b}^{+}\left(\mathrm{R}=\mathrm{NMe}_{2}\right)$, the positive charge is delocalized over C18 and C9 and over C19 and C24. DFT calculations were also performed on the bispyrylium species $\mathbf{3 a}^{2+}$ and its elusive reduced form 3a. Isodensity surfaces of the LUMO of $\mathbf{3} \mathbf{a}^{2+}$ and of the HOMO of $\mathbf{3 a}$ suggest that the electron transfer mainly occurs on the pyrylium moieties and not on the R-substituted phenyl groups (Figure S21). This result is consistent with electrochemical data showing a quasi-independency of the reduction potential of $\mathbf{3}^{2+}$ with R (Figure $\left.2 \mathrm{~A}\right)$.

To gain further support for these conclusions, the formal oxidation potentials of compounds 2a-f in dichloromethane were calculated by DFT using an isodesmic equation (see SI for computational details). As shown in Table 2, there is a good agreement between the measured and calculated values (i.e. the difference between the two values is typically below $100 \mathrm{mV}$ except for $\mathrm{R}=\mathrm{NO}_{2}$ ). Note also that the measured values are peak potential values of an oxidation step coupled with a fast chemical reaction. In addition, as shown in Figure $4 \mathrm{~A}$, plots of measured $\left(E_{\mathrm{pa}, \text { exp }}\right)$ and calculated $\left(\left(E_{\text {theor }}^{0}\right)\right.$ potentials vs. Brown constant $\left(\sigma^{+}\right)$show similar trends. Similarly, a formal reduction potential of $E_{\text {red }}^{0}=-0.73 \mathrm{~V}$ vs. Fc was calculated by DFT for the reduction of $\mathbf{3} \mathbf{a}^{2+}$ to 3a (Table S5), in good agreement with the experimental data shown in Figure 2. 

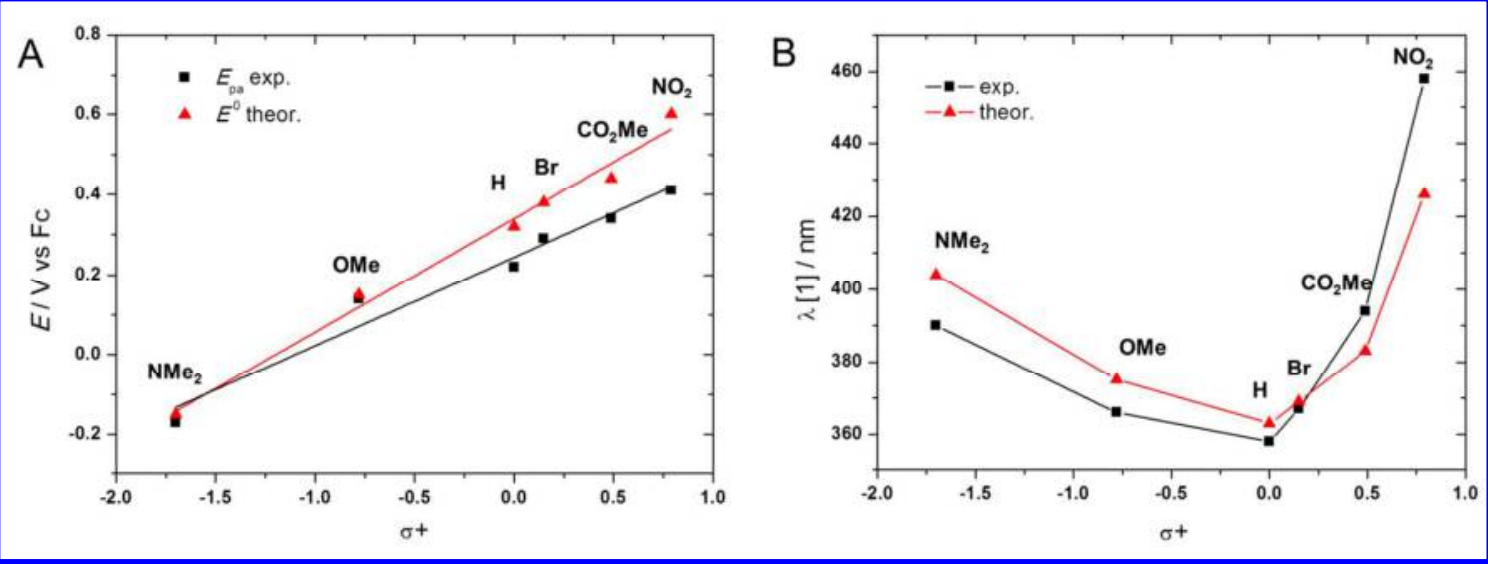

Figure 4. Plots of experimental (black squares) and calculated (red triangles) values of A) the oxidation potential in $\mathrm{CH}_{2} \mathrm{Cl}_{2} / \mathrm{NBu}_{4} \mathrm{PF}_{6}$ and B) the maximal wavelength $\lambda[1]$ in $\mathrm{CH}_{2} \mathrm{Cl}_{2}$ of ${ }^{\mathrm{R}} \mathrm{PhMP}$ 2a-f compounds against the Brown constant value of the $\mathrm{R}$ groups.

\section{$\underline{\mathrm{UV}-\mathrm{V} \text { is spectroscopic properties }}$}

UV-Vis spectroscopic properties of the 2a-f compounds were investigated. As shown in Figure 5 and Table 3, compounds 2a-f display three main absorption bands in the $250-500 \mathrm{~nm}$ optical range with high molar extinction coefficients of about $3 \times 10^{4}$ to $4 \times 10^{4} \mathrm{M}^{-1} \mathrm{~cm}^{-1}$. The absorption band displaying a maximum at $c a$. $\lambda[1]=400 \mathrm{~nm}$ is fully dependent on the nature $\mathrm{R}$ in contrast to the two others bands at $\lambda[2]=280 \mathrm{~nm}$ and $\lambda[3]=$ $250 \mathrm{~nm}$ (Figure 5). The $\lambda[1]$ absorption band has previously been reported for analogous methylenepyrans. ${ }^{37,38,41}$

In contrast to the value of the oxidation peak $E_{\mathrm{pa}}$, the value of $\lambda[1]$ does not vary linearly with the Brown constant value $\sigma^{+}$of the $\mathrm{R}$ groups (Figure $4 \mathrm{~B}$, black plots). Indeed, the $\mathrm{NO}_{2}$ substituted phenylmethylenepyran $\mathbf{2 f}$ displays the highest wavelength value at $460 \mathrm{~nm}$ within the 2a-f series. Compounds $\mathbf{2 b}$ and $\mathbf{2 d}$ display $\lambda[1]$ values around $390 \mathrm{~nm}$, whereas compounds $\mathbf{2 a}, \mathbf{2 c}$ and $\mathbf{2 e}$ absorb around $360 \mathrm{~nm}$. 


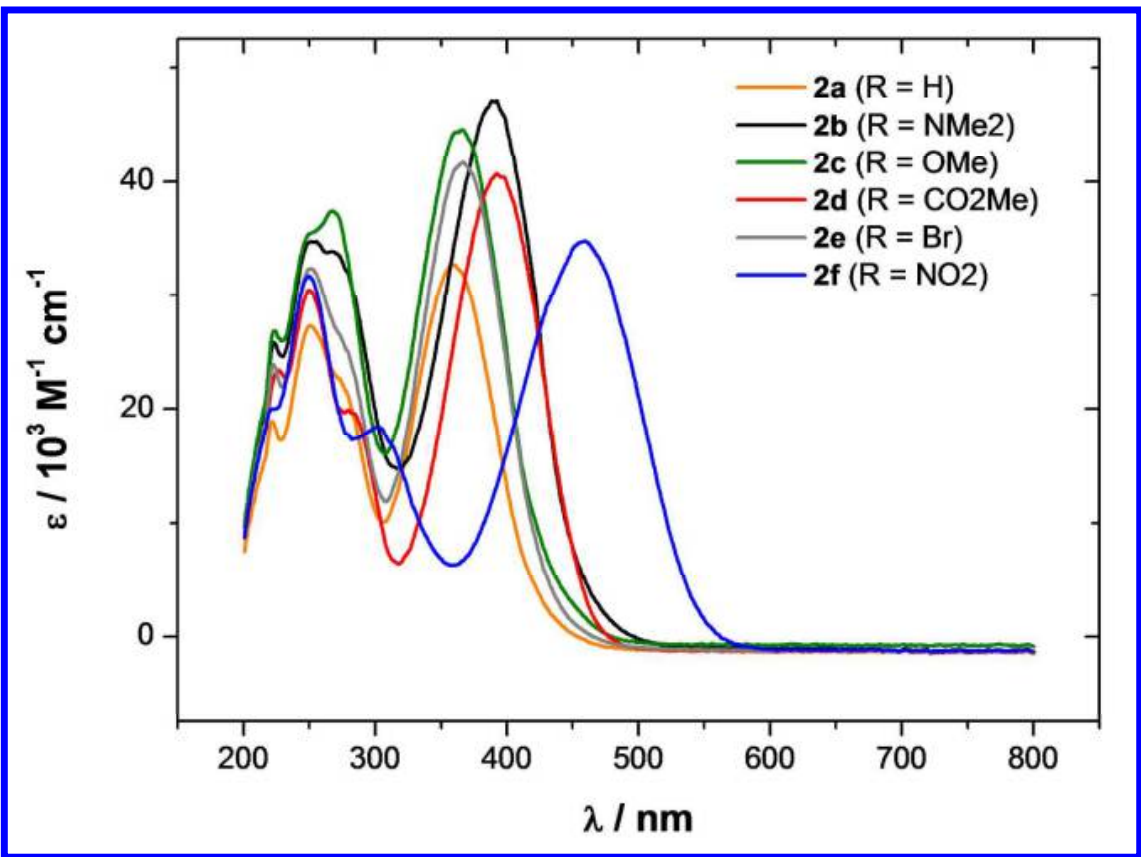

Figure 5. UV-Vis spectra (optical path of $1 \mathrm{~mm})$ of $\mathbf{2} \mathbf{a}-\mathbf{f}$ compounds $\left(0.25 \mathrm{mM}\right.$ in $\left.\mathrm{CH}_{2} \mathrm{Cl}_{2}\right)$ : $\mathbf{2 a}(\mathrm{R}=\mathrm{H}$, orange), $\mathbf{2 b}\left(\mathrm{R}=\mathrm{NMe}_{2}\right.$, blue), $\mathbf{2} \mathbf{c}(\mathrm{R}=\mathrm{Br}$, green $), \mathbf{2 d}\left(\mathrm{R}=\mathrm{CO}_{2} \mathrm{Me}\right.$, red $), \mathbf{2 e}\left(\mathrm{R}=\mathrm{OMe}\right.$, gray), $\mathbf{2 f}\left(\mathrm{R}=\mathrm{NO}_{2}\right.$, black $)$.

TD-DFT calculations were hence carried out to investigate the non-linear variation of $\lambda[1]$ with $\sigma^{+}$(See SI for computational details). As shown in Figure 4B, the close agreement between the calculated and experimental wavelength values $\lambda[1]$ indicates that the computational method is able to model the effect of electron donating/withdrawing properties of the R group on the UV-vis spectra (Figure S24). A close inspection of the energy level diagram shows that the absorption band at $\lambda[1]$ for all these compounds mainly concerns the HOMO-LUMO transition (ca. 80\%). Actually, the bowl-shape of the $\lambda[1]$ vs. $\sigma^{+}$plot can be analyzed according to the respective variation of the energy level of the HOMO and the LUMO with the value of the Brown constant (Figure S23). The energy levels of both the HOMO and the LUMO decrease with increasing values of $\sigma^{+}$. However, the energy level of the LUMO decreases sharply when the R substituting group becomes very electrophilic (i.e. corresponding to a high value of $\sigma^{+}$), which explains the bowl-shape of the HOMO-LUMO energy difference vs. $\sigma^{+}$plot, and hence that of the $\lambda[1]$ vs. $\sigma^{+}$plot. 
Table 3. UV-Vis spectroscopic data $\left(\lambda / \mathrm{nm}\right.$ and $\left.\varepsilon / \mathrm{M}^{-1} \mathrm{~cm}^{-1}\right)$ for compounds $\mathbf{2 a - f}$ in $\mathrm{CH}_{2} \mathrm{Cl}_{2}$.

\begin{tabular}{cllll}
\hline Compound & $\mathbf{R}$ & $\boldsymbol{\lambda}[\mathbf{1}](\boldsymbol{\varepsilon})$ & $\boldsymbol{\lambda}[\mathbf{2}](\boldsymbol{\varepsilon})$ & $\boldsymbol{\lambda [ 3 ] ( \boldsymbol { \varepsilon } )}$ \\
\hline $\mathbf{2 a}$ & $\mathrm{H}$ & $358(32600)$ & $274(22400)$ & $252(27200)$ \\
$\mathbf{2 b}$ & $\mathrm{NMe}_{2}$ & $390(47120)$ & $269(34000)$ & $252(34800)$ \\
$\mathbf{2 c}$ & $\mathrm{OMe}$ & $366(44560)$ & $271(37600)$ & $252(35600)$ \\
$\mathbf{2 d}$ & $\mathrm{CO}_{2} \mathrm{Me}$ & $394(40480)$ & $285(19600)$ & $250(30000)$ \\
$\mathbf{2 e}$ & $\mathrm{Br}$ & $367(41480)$ & $280(24800)$ & $251(32200)$ \\
$\mathbf{2 f}$ & $\mathrm{NO}_{2}$ & $458(34800)$ & $302(18400)$ & $248(31600)$ \\
\hline
\end{tabular}

\section{$\underline{\text { Redox switch monitoring by spectroelectrochemistry }}$}

Electrochemical studies showed that the process of $\mathrm{C}-\mathrm{C}$ dimerization of $\mathbf{2 a}-\mathbf{f}$ leading to the corresponding bispyrylium dication $\mathbf{3 a - \mathbf { f } ^ { 2 + }}$ is relatively fast because a reversible CV response started being observed for $v>20$ $\mathrm{V} \mathrm{s}^{-1}$ (Figure S2). Reduction of these products induces fast C-C bond breaking and recovering of the initial pyran compounds. Taking advantage of the relative pace of these two processes, UV-Vis spectroelectrochemistry experiments were carried out in $\mathrm{CH}_{2} \mathrm{Cl}_{2} / \mathrm{Bu}_{4} \mathrm{NPF}_{6}$ by applying potential steps to check the reversibility of the switch by electrochemical input from 2 to $\mathbf{3}^{\mathbf{2 +}}$ species (see for example Figure 6 for $\mathbf{2 f}$ ). A specifically design thin-layer cell of $0.2 \mathrm{~mm}$ optical path, allowed us to work in a reflectance mode as previously described for other compounds. ${ }^{50}$ We particularly focused on the absorption band at $\lambda[1]$ because of the targeted objective to use these compounds as optical switches in the visible range. Table 4 displays the values of absorption band recorded upon fast electrochemical potential switching between $\mathbf{2}$ and $\mathbf{3}^{\mathbf{2}}$. Whereas the value of $\lambda[1]$ is fully dependent on the nature of $\mathrm{R}$, the absorption band at $\lambda[4]$ for the electrochemically generated bispyrylium $3^{2+}$ is almost the same for all compounds (405 to $419 \mathrm{~nm}$, Table 4). As a consequence, the change in applied potential induces a bathochromic shift for $\mathbf{2 a - e}$ compounds, while the nitro-based $\mathbf{2 f}$ pyran displays a hypsochromic shift. DFT calculations performed on the H-substituted bispyrylium $\mathbf{3 a ^ { 2 + }}$ and its doubly-reduced form $\mathbf{3 a}$ display good matching between theoretical and experimental values of $\lambda[4]$ (Table 4 and Figure S25). According to DFT calculations, this absorption band reflects the HOMO-LUMO gap for the bispyrylium compounds.

In order to evaluate the stability of both two stable states (pyran and bis-pyrylium) upon redox switch, UVvisible monitoring was performed under thin-layer conditions for 15 cycles for compounds 2a-f. As shown in Figure 6 for $\mathbf{2 f}$, a progressive decrease and broadening of the absorbance at $\lambda[1]$ and $\lambda[4]$ was detected, as well as an increase of the absorption band at $250 \mathrm{~nm}$. This suggests the formation of a new species upon cycling 
which absorbs in both $400-500 \mathrm{~nm}$ and $250 \mathrm{~nm}$ regions. This was confirmed by thin-layer cyclic voltammetry which showed the appearance of a new redox reversible system at ca. $E^{0^{\prime}}=-0.05 \mathrm{~V}$ vs. Fc, with a progressive decrease of the anodic peak current related to the oxidation of the methylenepyran. This system kept on growing continuously after several cycles (Figure S3). Noticeably, it did not appear when the study was operated under diffusing conditions and at low scan rate $\left(0.02 \mathrm{~V} \mathrm{~s}^{-1}\right)$, indicating a rather slow reaction at the electrode surface (Figure S3). Accordingly, this new redox system can be ascribed to the reversible oxidation of the bispyran 4a-f (Scheme 4) resulting from the deprotonation of the bispyrylium $\mathbf{3 a}-\mathbf{f}^{2+}$, in agreement with previous studies. ${ }^{42,43}$ This was confirmed by the electrochemical studies of the chemically synthesized bispyran $\mathbf{4 f}$ in dichloromethane which displays a reversible system at $E^{0}=-0.07 \mathrm{~V}$ vs $\mathrm{Fc}$ involving two electrons (Figure S6), as clearly demonstrated by exhaustive electrolysis of the solution. In addition, the UV-Vis spectrum of $\mathbf{4 f}$ in dichloromethane features three main bands at $484 \mathrm{~nm}, 398 \mathrm{~nm}$ and $259 \mathrm{~nm}$ (Figure S8). Similarly to compounds $\mathbf{2 a}-\mathbf{f}$ and $3 \mathbf{a}^{2+}$, a formal potential was calculated by DFT for the two-electron oxidation of $\mathbf{4 f}$. The value found $\left(E^{0}=0.19 \mathrm{~V}\right.$ vs $\left.\mathrm{Fc}\right)$ is in good agreement with the experimental data (Table S5). Moreover, the UV-Vis spectra for $\mathbf{4 f}$ calculated from TD-DFT displays absorption bands at $455 \mathrm{~nm}, 355 \mathrm{~nm}$ and $273 \mathrm{~nm}$ (Figure S26), in good agreement with the values found experimentally.

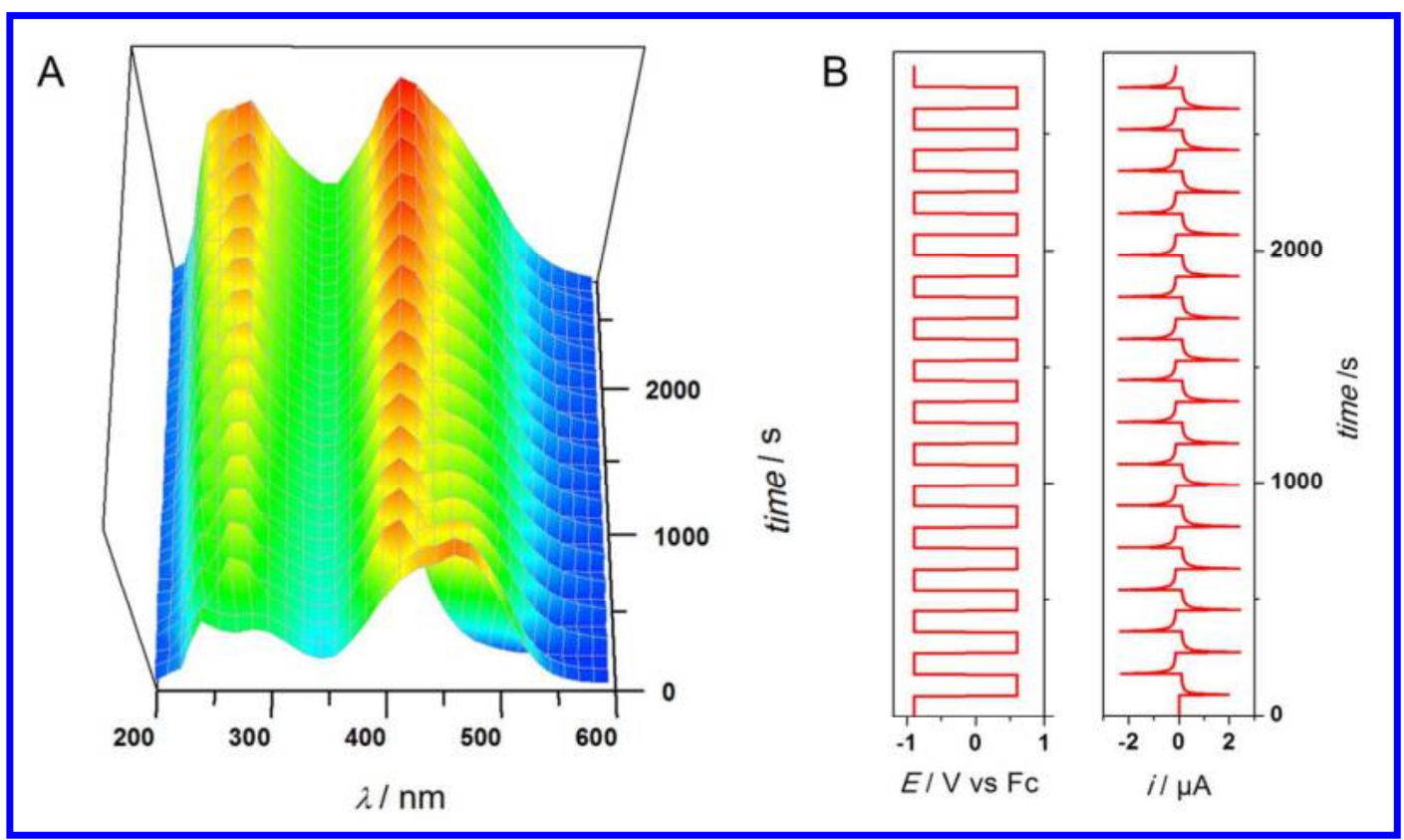

Figure 6. A) Time-resolved monitoring of the UV-Vis characterization of compound $\mathbf{2} \mathbf{f}$ in $\mathrm{CH}_{2} \mathrm{Cl}_{2} / \mathrm{NBu}_{4} \mathrm{PF}_{6} 0.1$ $\mathrm{M}$ upon redox switching between $0.6 \mathrm{~V}$ and $-0.9 \mathrm{~V}$ vs. Fc (15 cycles of 180 seconds) (optical path: $0.2 \mathrm{~mm}) . \mathrm{B}$ ) Plots of applied potential (left) and resulting current (right) against time during the monitoring. 
Table 4. Experimental and theoretical UV-Vis spectroscopic data $\left(\lambda_{\max } / \mathrm{nm}\right)$ for compounds $\mathbf{2 a - f}$ and $\mathbf{3 a - \mathbf { f } ^ { 2 + }}$ in $\mathrm{CH}_{2} \mathrm{Cl}_{2} / \mathrm{NBu}_{4} \mathrm{PF}_{6} 0.1 \mathrm{M}$.

\begin{tabular}{|c|c|c|c|c|c|c|}
\hline $\mathbf{R}$ & Compound & $\lambda[1]$ & & Compound & $\lambda[4]$ & \\
\hline & & Exp. & Theor. $^{\mathrm{a}}$ & & Exp. & Theor. $^{\mathrm{a}}$ \\
\hline $\mathrm{H}$ & $2 a$ & 358 & 364 & $3 \mathbf{a}^{2+}$ & 405 & 398 \\
\hline $\mathrm{NMe}_{2}$ & $2 b$ & 390 & 404 & $3 b^{2+}$ & 411 & $\mathrm{~b}$ \\
\hline $\mathrm{OMe}$ & $2 c$ & 366 & 378 & $3 c^{2+}$ & 405 & $\mathrm{~b}$ \\
\hline $\mathrm{CO}_{2} \mathrm{Me}$ & 2d & 394 & 383 & $3 d^{2+}$ & 415 & $\mathrm{~b}$ \\
\hline $\mathrm{Br}$ & $2 e$ & 367 & 369 & $3 \mathrm{e}^{2+}$ & 407 & $\mathrm{~b}$ \\
\hline $\mathrm{NO}_{2}$ & $2 f$ & 458 & 426 & $3 f^{2+}$ & 419 & $\mathrm{~b}$ \\
\hline
\end{tabular}

Hence, at the first cycle, oxidation of $\mathbf{2 a - f}$ leads to formation of the bispyrylium $\mathbf{3 a -} \mathbf{f}^{2+}$ by C-C bond making, which partly undergoes deprotonation and forms the $\mathbf{4 a - f}$ species. On application of a low redox potential of -0.9 $\mathrm{V}$ vs. Fc, the electrochemically generated compound $\mathbf{3 a -} \mathbf{f}^{2+}$ is reduced into $\mathbf{2 a - f}$ by C-C bond breaking. As long as the switching cycle is maintained, each new cycle leads to a slight decrease of the concentration in bispyrylium, as well as an increase in concentration in bispyran within the thin layer. This induces a modification of the UV-Vis spectroscopic response by coalescence of the different absorption bands. The formation of this new species 4a-f was observed by thin-layer CV for all phenylmethylenepyrans (Figures S4 and S5). The formal potential of the electrochemically generated bispyran was almost insensitive to the nature of the R substituting group. This is in agreement with DFT calculations performed for $\mathbf{4 f}$ which suggest that oxidation involves molecular orbitals situated on the central core of the bispyran (Figure S27).

Insights into the variation of the absorption maxima upon cycling showed slight discrepancies between 2a-f compounds. For instance, a quasi-constant UV-Vis response was recorded for both neutral $\mathbf{2 f}$ and oxidized $\mathbf{3 \mathbf { f } ^ { 2 + }}$ species after 5 cycles (Figure 7A). Such result suggests that deprotonation does not interfere in the $\mathbf{2 f - 3 \mathbf { f } ^ { 2 + }}$ switching process after a few cycles. In contrast, switching between $\mathbf{2 c}$ and $3 \mathbf{c}^{2+}$ induced a progressive decrease of the band at $405 \mathrm{~nm}$, as an indicator of a constant decrease of the concentration in bis-pyrylium $3 \mathbf{c}^{2+}$ within the thin layer (Figure 7B). Moreover, the oxidation of the pyran $2 \mathbf{c}$ did not lead to a total decrease of the band at 366 $\mathrm{nm}$, and reduction of $\mathbf{3} \mathbf{c}^{2+}$ failed at removing total absorption at $405 \mathrm{~nm}$. This effect was also observed for $\mathbf{2 b}$ (Figure S11), but not for 2a, 2d and 2e (Figures S10, S13 and S14). For R=OMe, it can ascribed to the formation of the bispyran $\mathbf{4 c}$ and its oxidized analog $4 \mathbf{c}^{2+}$ in the thin layer, these two species likely absorbing in the 350 - 
$500 \mathrm{~nm}$ wavelength range as found for $\mathbf{4 f}$ and $\mathbf{4} \mathbf{f}^{2+}$ (Figures S8 and S17). This discrepancy is consistent with the Bronsted basicity strength of the substituting group R. Basic moieties such as $\mathrm{NMe}_{2}$ and $\mathrm{OMe}$ can indeed interact with protons of an adjacent bispyrylium compound and then favor deprotonation.

At last, attempts were made to avoid deprotonation of the bispyrylium (3a-f) $)^{2+}$, by adjusting pulse length in chronoamperometric studies or by decreasing phenylmethylenepyran concentration. Decreasing or increasing the pulse duration did not lead to any significant improvement of the electrochemical current and spectroscopic responses with cycling. We also investigated the effect of decreasing the concentration of phenylmethylenepyran in solution (i.e. [2f] $=0.15 \mathrm{mM}$, Figure S16), but no significant improvement in stability could be detected.
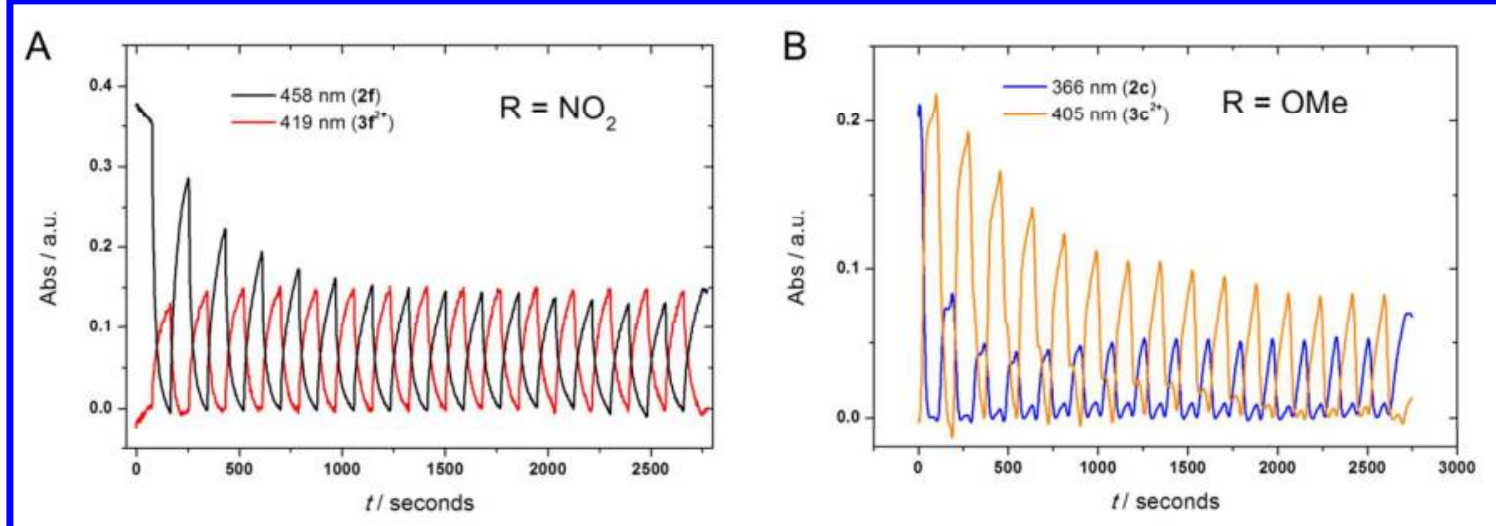

Figure 7. Plots of baseline -corrected absorbance vs time at different wavelengths starting from solutions of compounds $2 \mathbf{2 f}(\mathrm{A})$ and $\mathbf{2 c}$ (B) upon redox switching between $0.6 \mathrm{~V}$ and $-0.9 \mathrm{~V}$ vs. Fc (15 cycles of 180 seconds): A) $\lambda=458 \mathrm{~nm}$ (black, characterizing $\mathbf{2 f}$ ) and $419 \mathrm{~nm}$ (red, characterizing $\mathbf{3 f ^ { 2 + }}$ ); B) $\lambda=366 \mathrm{~nm}$ (blue, characterizing 2c) and $405 \mathrm{~nm}$ (orange, characterizing $3 \mathbf{c}^{2+}$ ). Experiments performed in $\mathrm{CH}_{2} \mathrm{Cl}_{2} / \mathrm{NBu}_{4} \mathrm{PF}_{6} 0.1 \mathrm{M}$ with concentration of $0.60 \mathrm{mM}$ in methylenepyran (optical path $0.2 \mathrm{~mm}$ ).

\section{Conclusion}

In summary, this work successfully demonstrates that tuning of the optical and redox properties of various phenylmethylenepyrans can be achieved by simple substitution on the para position of the phenylmethylene moiety. Voltammetric studies in organic media showed that all compounds undergo irreversible oxidation according to a fast dimerization process leading to bispyrylium species by intermolecular carbon-carbon bond formation. The electrochemical reduction of the resulting bispyrylium compounds yields back the initial pyran 
species by C-C bond breaking. Electrochemical data showed that the oxidation potential increases linearly with the electrophilic character of the substituting group, a result that is fully supported by DFT calculations. Contrarily, the reduction potential of $\mathbf{3}^{2+}$ remains almost insensitive to the nature of the $\mathrm{R}$ group. UV-Vis spectroscopic studies emphasize a wide variation of the optical properties of differently para-substituted phenylmethylenepyran compounds vs. bispyrylium, whith absorption bands shifted by over $100 \mathrm{~nm}$ in the 360 $460 \mathrm{~nm}$ wavelength range. In contrast to electrochemical results, the spectroscopic features of the phenylmethylenepyrans, which is well reproduced by TD-DFT calculations, do not vary linearly with the donor/withdrawing properties of the substituting moiety R. On the basis of the C-C bond making/breaking process, time-resolved spectroelectrochemical experiments in thin layer conditions have been carried out. Reversible optical changes associated to the electrochemical generation of pyran and bispyrylium species have been clearly emphasized. Redox-switching in thin-layer conditions suggests the progressive formation of a neutral bispyran moiety resulting from deprotonation of the bispyrylium compound over cycles, but in a much lower proportion than for dithiafulvene analogous systems. ${ }^{30}$ The deprotonation process seems being dependent on the nature of the R-substituting group. Noteworthy, the bispyran intermediate is only detected when cycling under thin-layer conditions.

From these results, it appears clearly that this series of compounds display remarkable properties for envisaging applications as redox switching devices. In particular, the nitro-based methylenepyran exhibits the most interesting properties, so far for this type of compound; that is : (i) fast chemical conversion between the two stable states; (ii) low oxidation potential; (iii) large shift of $100 \mathrm{~nm}$ of the absorption band in the visible region between stables states. Future work will aim at improving these characteristics, in particular for inhibiting the deprotonation process by rational design of new compounds based on the same skeleton and/or by variation of experimental conditions. Moreover, theoretical investigations by electrochemical and molecular modeling will be performed to analyze the mechanism of dimerization (i.e. RRD vs. RSD) and the possible effect of the nature of the R group on kinetics. 


\section{Experimental section}

\section{General procedures.}

All chemical manipulations were carried out under a nitrogen atmosphere using standard Schlenk-line Techniques. Infrared-spectra were recorded on a Perkin-Elmer spectrum1000 FTIR using KBr plates. All NMR data are reported in ppm $(\delta)$ relative to tetramethylsilane as external reference. Coupling constants are reported in $\mathrm{Hz} .{ }^{1} \mathrm{H}$ and ${ }^{13} \mathrm{C}$ NMR chemical shift assignments are supported by data obtained from ${ }^{1} \mathrm{H}-{ }^{1} \mathrm{H}$ cosy, ${ }^{1} \mathrm{H}-{ }^{13} \mathrm{C}$ HMQC and ${ }^{1} \mathrm{H}^{-13} \mathrm{C}$ HMBC. Spectra were recorded at room temperature in $\mathrm{CDCl}_{3}$ or acetone $\mathrm{d}_{6}$ on a Bruker Ascend TM 300 spectrometer. Mass spectra or elemental analyses were performed at the CRMPO (Université de Rennes). Microanalytical data were obtained with a Thermo-Finnigan Flasch EA 1112 CHNS/0 analyzer. Mass spectra were obtained with high resolution spectrometer (Waters Q-TOF-2 or Bruker MAXI 4G). X-ray crystal structure of compound $\mathbf{2 b}$ was obtained at $100 \mathrm{~K}$ from a single crystal grown from solution in dichloromethane at room temperature. Diffraction data were collected on an Oxford Diffraction X-Calibur diffractometer with attached Cryojet cryostat and Crysalis software using MoKo radiation at X-ray diffraction facilities of "Plateforme d'imagerie et de mesure en microscopie" (PIMM-DRX, Université de Bretagne Occidentale). Structure was solved by direct methods using SHELXS97 program and least-square refined using SHELXL97 program. ${ }^{51}$ Electrochemical studies of all compounds were performed in a glovebox (Jacomex) $\left(\mathrm{O}_{2}<1\right.$ ppm, $\mathrm{H}_{2} \mathrm{O}<1$ ppm) with a home-designed 3-electrodes cell (WE: Pt diam. 3mm or 1mm, RE: Pt wire in a $\mathrm{Fc}^{+} / \mathrm{Fc}$ solution, CE: graphite rod). Ferrocene was added at the end of the experiments to determine redox potential values. For all experiments, ohmic drop was determined by the positive feedback method. The potential of the cell was controlled by an AUTOLAB PGSTAT 100 (Metrohm) potentiostat monitored by the NOVA 1.11 software. Extra-dry dichloromethane (Acros) was stored in the glovebox and used as received. The supporting salt $\mathrm{NBu}_{4} \mathrm{PF}_{6}$ was synthesized from $\mathrm{NBu}_{4} \mathrm{OH}$ (Acros) and $\mathrm{HPF}_{6}$ (Aldrich). It was then purified, dried under vacuum for 48 hours at $100^{\circ} \mathrm{C}$, then kept under argon in the glovebox. Electrolyses were carried out with a homedesigned 3-electrodes cell (WE: graphite rod, RE: Pt wire, CE: graphite rod). Thin layer room UV-Vis spectroelectrochemistry was performed with a specific home-designed cell in a reflectance mode (WE: Pt diam 3mm, RE: Pt wire, CE: Pt wire) with an optical path of $0.2 \mathrm{~mm}^{50}$ The UV-Vis optic fibre probe used was purchased from Ocean Optics. Time-resolved UV-Vis detection was performed with QEPro spectrometer (Ocean optics). Classical UV-Vis spectroscopy in a $10 \mathrm{~mm}$ quartz cuvette was performed with the QEPro spectrometer. 


\section{Syntheses of compounds $2 a, 2 c, 2 d$ and $2 e$}

Syntheses of compounds $\mathbf{2 a},{ }^{44,45,55} \mathbf{2 c},{ }^{44,55} \mathbf{2 d}$, $^{41}$ and $\mathbf{2} \mathbf{e}^{46}$ were performed according to a previously published procedure based on a Wittig-type reaction:

Under nitrogen atmosphere, to a degassed solution of 2,6-diphenyl-4H-4-yl triphenylphosphonium tetrafluoroborate $\mathbf{1}^{\mathbf{P h}}$ or 2,6-diphenyl-4H-4-yl tributylphosphonium tetrafluoroborate salts $\mathbf{1}^{\mathbf{n}-\mathrm{Bu}}$ in THF, was added, dropwise at $-78^{\circ} \mathrm{C}$, a small excess of n-butyl-lithium solution (2.5 $\mathrm{M}$ in hexane) (Figure 1). After $15 \mathrm{~min}$, the corresponding aldehyde was added to the dark solution and the mixture was stirred $30 \mathrm{~min}$ at this temperature. The orange solution obtained was then allowed to room temperature for 3 hours. After evaporation of THF, water and methylene chloride were added to the residue and the aqueous layer was extracted three times with methylene chloride. The combined organic extracts were evaporated. The crude product was purified by silica gel column chromatography. ${ }^{1} \mathrm{H}$ NMR spectroscopy and mass spectrometry features of compounds $\mathbf{2 a}, \mathbf{2 c}$, $\mathbf{2 d}$ and $\mathbf{2 e}$ are given in references [41, 44-46, 55].

\section{4-(2,6-Diphenyl-pyran-4-ylidenemethyl)-dimethylaminobenzene (2b)}

The dimethylaminobenzene derivative was synthesized thanks to the same procedure as used for $\mathbf{2 a}, \mathbf{2 c}, \mathbf{2 d}$ and 2e except the nature of the phosphonium salt (tributyl instead of triphenyl one).

Reactants: diphenyl-4H-4-yl tributylphosphonium tetrafluoroborate salt (1g, $1.67 \mathrm{mmol})$, n-butyllithium 2.5M in hexanes ( $0.70 \mathrm{~mL}, 1.75 \mathrm{mmol}, 1.1 \mathrm{eq})$, 4-dimethylaminobenzaldehyde (0.249 g, $1.67 \mathrm{mmol}, 1 \mathrm{eq})$.

Chromatography: (diethyl ether/ Petroleum ether, 1/1)

Product obtained $(250 \mathrm{mg}, 41 \%)$ as orange solid mp: $180-182^{\circ} \mathrm{C} \mathrm{IR} \mathrm{v}\left(\mathrm{cm}^{-1}\right) 2853 ; 1656 ; 1604 ; 1514 ; 1493 ; 1065$; 936; 762. ${ }^{1} \mathrm{H}$ NMR (300 MHz, acetone d6) $\delta(\mathrm{ppm}) 7.89(\mathrm{~d}, 4 \mathrm{H}), 7.50(\mathrm{~d}, 6 \mathrm{H}), 7.34(\mathrm{~d}, \mathrm{~J}=6.7 \mathrm{~Hz}, 2 \mathrm{H}), 7.07$ $(\mathrm{d}, 1 \mathrm{H}), 6.78(\mathrm{~d}, \mathrm{~J}=8.0 \mathrm{~Hz}, 2 \mathrm{H}), 6.61(\mathrm{~d}, 1 \mathrm{H}), 5.95(\mathrm{~s}, 1 \mathrm{H}), 2.98(\mathrm{~s}, 6 \mathrm{H}){ }^{13} \mathrm{C}$ NMR and JMOD $(125 \mathrm{MHz}$, Acetone-d6) $\delta(\mathrm{ppm})$ 151. 6 (C),149.2 (C), 148.2 (C), 133.4 (C), 133.5 (C) $129.2(\mathrm{CH}), 128.5(\mathrm{CH}), 126.6(\mathrm{C})$, $125.9(\mathrm{C}) 125.2(\mathrm{CH}), 115.6(\mathrm{CH}), 112.3(\mathrm{CH}), 108.8(\mathrm{CH}), 101.9(\mathrm{CH}), 39.7(\mathrm{CH})$. HRMS (ESI/ASAP) m/z calculated for $\mathrm{C}_{26} \mathrm{H}_{24} \mathrm{NO}[\mathrm{M}+\mathrm{H}]^{+} 366.18579$, found 366.1855 (1ppm).

\section{4-(2,6-Diphenyl-pyran-4-ylidenemethyl)-nitrobenzene (2f)}

A solution of n-BuLi $(0.2 \mathrm{~mL}, 2.5 \mathrm{M}$ in pentane) was added to a solution of diphenyl-4H-4-yl tributylphosphonium tetrafluoroborate salt $(1 \mathrm{~g}, 1.92 \mathrm{mmol})$ in THF $(30 \mathrm{~mL})$ at $-78{ }^{\circ} \mathrm{C}$ under nitrogen. The reaction mixture was stirred at this temperature for $15 \mathrm{~min}$, and 4-nitro-benzaldehyde $0.290 \mathrm{~g}, 1.92$ 
mmol) was added. The resulted mixture was allowed to warm to room temperature and stirred for $2 \mathrm{~h}$. The solvent was removed and the residue was purified by column chromatography $\left(\mathrm{SiO}_{2}\right.$, Petroleum Ether $/ \mathrm{CH}_{2} \mathrm{Cl}_{2} 50 / 50$ ) to give compound $\mathbf{2 f}$ as red solid (630 $\left.\mathrm{mg}, 85 \%\right)$.

${ }^{1} \mathrm{H}$ NMR $\left(300 \mathrm{MHz}, \mathrm{CDCl}_{3}\right), \delta(\mathrm{ppm}) 8.22(\mathrm{~d}, \mathrm{~J}=8.0 \mathrm{~Hz}, 2 \mathrm{H}), 7.77-7.83(\mathrm{~m}, 4 \mathrm{H}), 7.45-7.55(\mathrm{~m}, 8 \mathrm{H}), 7.06(\mathrm{~d}, \mathrm{~J}=$ $1.0 \mathrm{~Hz}, 1 \mathrm{H}), 6.51(\mathrm{~d}, \mathrm{~J}=1.0 \mathrm{~Hz}, 1 \mathrm{H}), 5.97(\mathrm{~s}, 1 \mathrm{H}) ; \mathrm{JMOD}\left(125 \mathrm{MHz}, \mathrm{CDCl}_{3}\right) \delta(\mathrm{ppm}) 154.6(\mathrm{C}), 152.5(\mathrm{C})$, $148.2(\mathrm{C}), 145.8(\mathrm{C}), 133.3(\mathrm{C}), 132.9(\mathrm{C}), 132.5(\mathrm{C}), 130-124\left(\mathrm{CH}_{\mathrm{Ph}}\right), 111.8(\mathrm{CH}), 108.6(\mathrm{CH}), 101.6(\mathrm{CH})$ HRMS (ASAP/Q-tof 2) m/z calculated for $\mathrm{C}_{24} \mathrm{H}_{17} \mathrm{NO}_{3}[\mathrm{M}]^{+}: 367.12084$; found : $367.1206 ; \mathrm{m} / \mathrm{z}$ calculated for $\mathrm{C}_{24} \mathrm{H}_{18} \mathrm{NO}_{3}[\mathrm{M}+\mathrm{H}]^{+}:$368.12867; found : 368.1274 .

\section{4,4'-(1,2-bis(4-nitrophenyl)ethane-1,2-diyl)bis(2,6-diphenylpyrylium) tetrafluoroborate $\left(3 \mathrm{f}^{2+}, 2 \mathrm{BF}_{4}{ }^{-}\right)$}

Compound $2 \mathbf{f}(0.300 \mathrm{~g}, 0.816 \mathrm{mmol})$ and $\mathrm{AgBF}_{4}(0.159 \mathrm{~g}, 0.816 \mathrm{mmol})$ were stirred one hour in a degassed solution of methylene chloride $(30 \mathrm{~mL})$ at room temperature. The yellow solution turns green and we observe a black deposition of Ag residue which was then removed by filtration. The solution was then placed in a fridge ($20^{\circ} \mathrm{C}$ ) and after $24 \mathrm{~h}$ a green precipitate was observed and isolated by filtration (502mg, 68\%).

${ }^{1} \mathrm{H}$ NMR (300 MHz, $\mathrm{CD}_{2} \mathrm{Cl}_{2}$ ), 2 diastereoisomers (A: Maj. 67\% ; B : min. 33\%) $\delta 9.21$ (s, 2H, $\mathrm{H}_{\mathrm{A}}(3,5)$ ), 9.12 (s, 1H, $\left.\mathrm{H}_{\mathrm{B}}(3,5)\right), 8.46\left(\mathrm{~m}, 4 \mathrm{H}, \mathrm{H}_{\mathrm{A}}(\mathrm{Ph})\right), 8.40\left(\mathrm{~m}, 2 \mathrm{H}, \mathrm{H}_{\mathrm{B}}(\mathrm{Ph})\right), 8.38\left(\mathrm{~d}, \mathrm{~J}=9 \mathrm{~Hz}, 1 \mathrm{H}, \mathrm{H}_{\mathrm{B}}\left(\mathrm{PhNO}_{2}\right)\right), 8.23(\mathrm{~d}, \mathrm{~J}=9 \mathrm{~Hz}$, $\left.1 \mathrm{H}, \mathrm{H}_{\mathrm{B}}\left(\mathrm{PhNO}_{2}\right)\right), 8.16$ (d, J=9 Hz, 2H, $\left.\mathrm{H}_{\mathrm{A}}\left(\mathrm{PhNO}_{2}\right)\right), 8.09$ (d, J=9 Hz, 2H, $\left.\mathrm{H}_{\mathrm{A}}\left(\mathrm{PhNO}_{2}\right)\right)$, 7.88-7.74 (m, 9H, $\left.6 \mathrm{H}_{\mathrm{A}}(\mathrm{Ph})+6 \mathrm{H}_{\mathrm{B}}(\mathrm{Ph})\right), 6.50\left(\mathrm{~s}, 0.5 \mathrm{H}, \mathrm{H}_{\mathrm{B}}(7)\right), 6.45\left(\mathrm{~s}, 1 \mathrm{H}, \mathrm{H}_{\mathrm{A}}(7)\right)$. JMOD $\left(125 \mathrm{MHz}, \mathrm{CD}_{2} \mathrm{Cl}_{2}\right) \delta(\mathrm{ppm}) 172.3$ (C(2;6)), 172.1 (C2;6), 171.9 (C2;6), 147.9 (C11), 142.9(C4), $142.5(\mathrm{C}), 136.7(\mathrm{CH}), 130.5-124.9\left(\mathrm{CH}_{\mathrm{Ph}}\right), 127.8$ (C), $118.1(\mathrm{CH}(7))$. HRMS (ESI) $\mathrm{m} / \mathrm{z}$ calculated for $\mathrm{C}_{48} \mathrm{H}_{34} \mathrm{~N}_{2} \mathrm{O}_{6}[\mathrm{M}]^{2+}$ : 367.1203; found : 367.1199;

\section{1,2-bis(2,6-diphenyl-4H-pyran-4-ylidene)-1,2-bis(4-nitrophenyl)ethane (4f)}

Compound $2 \mathrm{f}(0.060 \mathrm{~g}, 0.163 \mathrm{mmol})$ and $\mathrm{AgBF}_{4}(0.032 \mathrm{~g}, 0.163 \mathrm{mmol})$ were stirred one hour in a degassed solution of methylene chloride $(10 \mathrm{~mL})$ at room temperature. $\mathrm{A} \mathrm{pH}=9$ glycine buffer was then added to the solution and the heterogeneous mixture was stirred for half an hour. The Ag residue was then eliminated by filtration and the organic layer was extracted 3 times using diethylether and washed 3 times with water. The extract was dried over $\mathrm{MgSO}_{4}$. After evaporation of the solvent, the crude product was obtained without further purification as a brown powder $(0.035 \mathrm{mg}, 30 \%)$. 
${ }^{1} \mathrm{H}$ NMR $\left(300 \mathrm{MHz}, \mathrm{CDCl}_{3}\right), \delta 8.12(\mathrm{~d}, \mathrm{~J}=6.9 \mathrm{~Hz}, 2 \mathrm{H}), 7.74(\mathrm{~m}, 2 \mathrm{H}), 7.67(\mathrm{~m}, 2 \mathrm{H}), 7.53(\mathrm{~d}, \mathrm{~J}=6.9 \mathrm{~Hz}, 2 \mathrm{H}), 7.46$ (m, 3H), $7.37(\mathrm{~m}, 3 \mathrm{H}), 6.98(\mathrm{~s}, 1 \mathrm{H}), 6.56(\mathrm{~s}, 1 \mathrm{H}) . \mathrm{JMOD}\left(125 \mathrm{MHz}, \mathrm{CDCl}_{3}\right) \delta(\mathrm{ppm}) 154.1(\mathrm{C}), 153.2(\mathrm{C}), 148.1$ (C), 145.7 (C), 132.9 (C), 132.8 (C), 131.7 (C), 130-124 ( $\left.\mathrm{CH}_{\mathrm{Ph}}\right), 121.2(\mathrm{C}), 105.8(\mathrm{CH}), 103.7$ (CH). HRMS (ESI) $\mathrm{m} / \mathrm{z}$ calculated for $\mathrm{C}_{48} \mathrm{H}_{32} \mathrm{~N}_{2} \mathrm{O}_{6}[\mathrm{M}]^{+}:$: 732.22549 ; found : 732.2255 (0 ppm); m/z calculated for $\mathrm{C}_{48} \mathrm{H}_{31} \mathrm{~N}_{2} \mathrm{O}_{6}[\mathrm{M}+\mathrm{Na}]^{+}:$755.21526; found : $755.2163(1 \mathrm{ppm}) ; \mathrm{m} / \mathrm{z}$ calculated for $\mathrm{C}_{48} \mathrm{H}_{31} \mathrm{~N}_{2} \mathrm{O}_{6}[\mathrm{M}-\mathrm{H}]^{+}$: 731.21766; found : $368.2192(2 \mathrm{ppm})$.

\section{Computational details.}

Structures of the compounds $\mathbf{2} \mathbf{a}-\mathbf{f}$ and $\mathbf{3} \mathbf{a}^{\mathbf{2 +}}$ and of their respectively oxidized and reduced forms were optimized in gas phase at the B3LYP/6-31G(d) level of theory as implemented in the Gaussian 09 software. ${ }^{52}$ Analytic frequency calculation was carried at the same level of theory on each optimized structures to identify the stationary point as a minimum (zero imaginary frequency) and to obtain the Gibbs free energy correction. The electronic energy in $\mathrm{CH}_{2} \mathrm{Cl}_{2}$ was derived from single point calculation at the B3LYP/6-31+G(d,p) level of theory starting from the gas-phase optimized structure and using the SMD continuum model. Time-dependent DFT (TD-DFT) was used to compute the excited states of $\mathbf{2 a - f}$ and $\mathbf{3} \mathbf{a}^{\mathbf{2}}$. Calculations were carried out at the B3LYP/def2-TVZP level of theory ${ }^{53}$ as implemented in the ORCA 3.03 software. $^{54}$ The isodensity surfaces were calculated and plotted using GaussView 5.0.9.

\section{Author Information \\ Corresponding author: \\ *Email: nicolas.lepoul@univ-brest.fr}

\section{Notes}

The authors declare no competing financial interest.

\section{Acknowledgments}

The authors thank the "Institut Brestois de Santé Agro Matière" (IBSAM) for their helpful financial contribution to the purchasing of the QEPro UV-Vis spectrometer. The "Centre Régional de Mesures Physiques de l'Ouest" (CRMPO, Université de Rennes) is thanked for mass spectrometry and elemental analyses. 
1

2

3

4

5

6

7

8

9

10

11

12

13

14

15

16

17

18

19

20

21

22

23

24

25

26

27

28

29

30

31

32

33

34

35

36

37

38

39

40

41

42

43

44

45

46

47

48

49

50

51

52

53

54

55

56

57

58

59

60

\section{Supporting Information}

Experimental details (electrochemistry, spectroelectrochemistry and DFT calculations). Crystal data are reported in Table S1. CCDC 1517637 contains the supplementary crystallographic data for this paper. The data can be obtained free of charge from The Cambridge Crystallographic Data Centre via www.ccdc.cam.ac.uk/structures 


\section{References}

1. $\quad$ Cai, G.; Wang, J.; Lee, P. S. Acc. Chem. Res. 2016, 49 (8), 1469-1476.

2. Erbas-Cakmak, S.; Leigh, D. A.; McTernan, C. T.; Nussbaumer, A. L. Chem. Rev. 2015, 115 (18), 10081-10206.

3. $\quad$ Tepper, C.; Haberhauer, G. Antioxid. Redox Signal. 2013, 19 (15), 1783-1791.

4. Le Poul, N.; Colasson, B. ChemElectroChem 2015, 2 (4), 475-496.

5. $\quad$ Kahlfuss, C.; Metay, E.; Duclos, M. C.; Lemaire, M.; Milet, A.; Saint-Aman, E.; Bucher, C. Chem. Eur. J. 2015, 21 (5), 2090-2106.

6. Woźny, M.; Pawłowska, J.; Osior, A.; Świder, P.; Bilewicz, R.; Korybut-Daszkiewicz, B. Chem. Sci. 2014, 5 (7), 2836-2842.

7. Doistau, B.; Benda, L.; Cantin, J. L.; Chamoreau, L. M.; Ruiz, E.; Marvaud, V.; Hasenknopf, B.; Vives, G. J.Am. Chem. Soc. 2017, 139 (27), 9213-9220.

8. $\quad$ Chen, Q.; Sun, J.; Li, P.; Hod, I.; Moghadam, P. Z.; Kean, Z. S.; Snurr, R. Q.; Hupp, J. T.;

Farha, O. K.; Stoddart, J. F. J.Am. Chem. Soc. 2016, 138 (43), 14242-14245.

9. $\quad$ Tseng, T.; Lu, H. F.; Kao, C. Y.; Chiu, C. W.; Chao, I.; Prabhakar, C.; Yang, J. S. J. Org. Chem. 2017, 82 (10), 5354-5366.

10. Gluyas, J. B.; Manici, V.; Guckel, S.; Vincent, K. B.; Yufit, D. S.; Howard, J. A.; Skelton, B. W.; Beeby, A.; Kaupp, M.; Low, P. J. J. Org. Chem. 2015, 80 (22), 11501-11512.

11. Kumar, K. R.; Kamei, T.; Fukaminato, T.; Tamaoki, N. ACS Nano 2014, 8 (5), 4157-4165.

12. Fihey, A.; Perrier, A.; Browne, W. R.; Jacquemin, D. Chem. Soc. Rev. 2015, 44 (11), 3719 3759 .

13. Kahlfuss, C.; Saint-Aman, E.; Bucher, Redox-Controlled Intramolecular Motions Triggered by $\pi$-Dimerization and Pimerization Processes. Wiley: 2015, p.39-88.

14. Tan, Y. S.; Yue, Y.; Webster, R. D. J. Phvs. Chem. B 2013, 117 (32), 9371-9379.

15. a) Macías-Ruvalcaba, N. A.; Evans, D. H. J. Electroanal. Chem. 2011, 660 (2), 243-246; b)

Astudillo Sánchez, P. D.; Evans, D. H. J. Electroanal. Chem. 2011, 660 (1), 91-96.

16. a) Suzuki, T.; Tamaoki, H.; Nishida, J.; Higuchi, H.; Iwai, T.; Ishigaki, Y.; Hanada, K.;

Katoono, R.; Kawai, H.; Fujiwara, K.; Fukushima, T. Redox-Mediated Reversible $\sigma$-Bond FormationCleavage. In Organic Redox Systems: Synthesis, Properties, and Applications; Nishinaga, T., Eds.;

Wiley, 2015; pp 13-38; b) Suzuki, T.; Ohta, E.; Kawai, H.; Fujiwara, K.; Fukushima, T. Synlett, 2007, 851; c) Suzuki, T.; Higuchi, H.; Tsuji, T.; Nishida, J.; Yamashita, Y.; Miyashi, T. Dynamic Redox Systems: Toward the Realization of Unimolecular Memory. In Chemistry of Nanomolecular Systems; Nakamura, T.; Matsumoto, T.; Tada, H.; Sugiura, K., Eds.; Springer, 2003; pp 3-24.

17. Macías-Ruvalcaba, N. A.; Felton, G. A. N.; Evans, D. H. J.Phvs. Chem. C 2009, 113 (1), 338 345.

18. Gallardo, I.; Guirado, G.; Marquet, J.; Vila, N. Angew. Chem. Int. Ed. Engl. 2007, 46 (8), $1321-1325$.

19. Brandt, J. R.; Pospisil, L.; Bednarova, L.; da Costa, R. C.; White, A. J. P.; Mori, T.; Teply, F.; Fuchter, M. J. Chem. Commun. 2017, 53 (65), 9059-9062.

20. Hong, F. J.; Low, Y. Y.; Chong, K. W.; Thomas, N. F.; Kam, T. S. J. Org. Chem. 2014, 79 (10), 4528-4543.

21. Yurchenko, O.; Freytag, D.; zur Borg, L.; Zentel, R.; Heinze, J.; Ludwigs, S. J. Phys. Chem. B 2012, $116(1), 30-39$.

22. Zheng, X.; Wang, X.; Qiu, Y.; Li, Y.; Zhou, C.; Sui, Y.; Li, Y.; Ma, J.; Wang, X. J. Am. Chem. Soc. 2013, 135 (40), 14912-5.

23. Teplý, F.; Č́žková, M.; Slavíček, P.; Kolivoška, V.; Tarábek, J.; Hromadová, M.; Pospíšil, L. J. Phvs. Chem. C 2012, 116 (5), 3779-3786.

24. John, H.; Briehn, C.; Schmidt, J.; Hunig, S.; Heinze, J. Angew. Chem. Int. Ed. Engl. 2007, 46 (3), 449-453.

25. Chen, X.; Wang, X.; Zhou, Z.; Li, Y.; Sui, Y.; Ma, J.; Wang, X.; Power, P. P. Angew. Chem. Int. Ed. Engl. 2013, 52 (2), 589-592.

26. Ivashenko, O.; van Herpt, J. T.; Feringa, B. L.; Rudolf, P.; Browne, W. R. J. Phys. Chem. C 2013, $117(36), 18567-18577$. 
27. Kortekaas, L.; Ivashenko, O.; van Herpt, J. T.; Browne, W. R. J.Am.Chem. Soc. 2016, 138 (4), 1301-1312.

28. Heinze, J.; Willmann, C.; Bäuerle, P. Angew. Chem. Int. Ed. Engl. 2001, 40 (15), 2861-2864.

29. Ohtake, T.; Tanaka, H.; Matsumoto, T.; Kimura, M.; Ohta, A. J. Org. Chem. 2014, 79 (14), 6590-6602.

30. Hapiot, P.; Lorcy, D.; Tallec, A.; Carlier, R.; Robert, A. J.Phvs. Chem. 1996, 100 (35), $14823-14827$.

31. Guerro, M.; Carlier, R.; Boubekeur, K.; Lorcy, D.; Hapiot, P. J.Am. Chem. Soc. 2003, 125 (10), 3159-3167.

32. Woolridge, K.; Goncalves, L. C.; Bouzan, S.; Chen, G.; Zhao, Y. Tetrahedron Lett. 2014, 55 (46), 6362-6366.

33. Adows, H.; Zhao, Y. Chem. Commun. 2016, 52 (89), 13101-13104.

34. Marchante, E.; Maglione, M. S.; Crivillers, N.; Rovira, C.; Mas-Torrent, M. RSC Adv. 2017, 7 (10), 5636-5641.

35. Casado-Montenegro, J.; Marchante, E.; Crivillers, N.; Rovira, C.; Mas-Torrent, M. Chemphvschem 2016, 17 (12), 1810-1814.

36. Gauthier, S.; Caro, B.; Robin-Le Guen, F.; Bhuvanesh, N.; Gladysz, J. A.; Wojcik, L.; Le Poul, N.; Planchat, A.; Pellegrin, Y.; Blart, E.; Jacquemin, D.; Odobel, F. Dalton Trans. 2014, 43 (29), 11233-11242.

37. Achelle, S.; Kahlal, S.; Saillard, J.-Y.; Cabon, N.; Caro, B.; Robin-le Guen, F. Tetrahedron 2014, 70 (17), 2804-2815.

38. Gauthier, S.; Vologdin, N.; Achelle, S.; Barsella, A.; Caro, B.; Robin-le Guen, F. Tetrahedron 2013, 69 (39), 8392-8399.

39. Martinez de Baroja, N.; Garin, J.; Orduna, J.; Andreu, R.; Blesa, M. J.; Villacampa, B.; Alicante, R.; Franco, S. J. Org. Chem. 2012, 77 (10), 4634-4644.

40. Ba, F.; Cabon, N.; Robin-Le Guen, F.; Le Poul, P.; Le Poul, N.; Le Mest, Y.; Golhen, S.; Caro, B. Organometallics 2008, 27 (24), 6396-6399.

41. Novoa, N.; Roisnel, T.; Dorcet, V.; Hamon, J.-R.; Carrillo, D.; Manzur, C.; Robin-Le Guen, F.; Cabon, N. J. Organomet. Chem. 2014, 762, 19-28.

42. Ba, F.; Robin-Le Guen, F.; Cabon, N.; Le Poul, P.; Golhen, S.; Le Poul, N.; Caro, B. J. Organomet. Chem. 2010, 695 (2), 235-243.

43. $\quad$ Ba, F.; Cabon, N.; Le Poul, P.; Kahlal, S.; Saillard, J.-Y.; Le Poul, N.; Golhen, S.; Caro, B.; Robin-Le Guen, F. New J. Chem. 2013, 37 (7), 2066-2081.

44. Katritzky, A. R.; Czerney, P.; Levell, J. R. J. Org. Chem. 1997, 62 (23), 8198-8200.

45. Reynolds, G. A.; Chen, C. H. J. Org. Chem. 1980, 45 (12), 2458-2459.

46. Vologdin, N.; Gauthier, S.; Achelle, S.; Caro, B.; Robin-le Guen, F. Lett. Org. Chem. 2014, 11 (8), 606-614.

47. Le Poul, P.; Le Poul, N.; Golhen, S.; Robin-Le Guen, F.; Caro, B. New J. Chem. 2016, 40 (7), 5666-5669.

48. Savéant, J.-M. Elements of Molecular and Biomolecular Electrochemistry: An Electrochemical Approach to Electron Transfer Chemistry. Wiley: 2006.

49. Bard, A. J.; Faulkner, L. R. Electrochemical Methods: Fundamentals and Applications. Wiley: 2000 .

50. Isaac, J. A.; Gennarini, F.; Lopez, I.; Thibon-Pourret, A.; David, R.; Gellon, G.; Gennaro, B.; Philouze, C.; Meyer, F.; Demeshko, S.; Le Mest, Y.; Reglier, M.; Jamet, H.; Le Poul, N.; Belle, C. Inorg. Chem. 2016, 55 (17), 8263-8266.

51. Sheldrick, G. M. Acta Crvst. A 2008, 64 (Pt 1), 112-122.

52. Frisch, M. J.; Trucks, G. W.; Schlegel, H. B.; Scuseria, G. E.; Robb, M. A.; Cheeseman, J. R.; Scalmani, G.; Barone, V.; Mennucci, B.; Petersson, G. A.; Nakatsuji, H.; Caricato, M.; Li, X.; Hratchian, H. P.; Izmaylov, A. F.; Bloino, J.; Zheng, G.; Sonnenberg, J. L.; Hada, M.; Ehara, M.; Toyota, K.; Fukuda, R.; Hasegawa, J.; Ishida, M.; Nakajima, T.; Honda, Y.; Kitao, O.; Nakai, H.; Vreven, T.; Montgomery Jr., J. A.; Peralta, J. E.; Ogliaro, F.; Bearpark, M. J.; Heyd, J.; Brothers, E. N.; Kudin, K. N.; Staroverov, V. N.; Kobayashi, R.; Normand, J.; Raghavachari, K.; Rendell, A. P.; Burant, J. C.; Iyengar, S. S.; Tomasi, J.; Cossi, M.; Rega, N.; Millam, N. J.; Klene, M.; Knox, J. E.; Cross, J. B.; Bakken, V.; Adamo, C.; Jaramillo, J.; Gomperts, R.; Stratmann, R. E.; Yazyev, O.; 
Austin, A. J.; Cammi, R.; Pomelli, C.; Ochterski, J. W.; Martin, R. L.; Morokuma, K.; Zakrzewski, V. G.; Voth, G. A.; Salvador, P.; Dannenberg, J. J.; Dapprich, S.; Daniels, A. D.; Farkas, Ö.; Foresman, J. B.; Ortiz, J. V.; Cioslowski, J.; Fox, D. J. Gaussian 09, Gaussian, Inc.: Wallingford, CT, USA, 2009. 53. Weigend, F.; Ahlrichs, R. Phvs. Chem. Chem. Phvs. 2005, 7 (18), 3297-3305.

54. Neese, F. Wilev Interdisciplinarv Reviews: Computational Molecular Science 2012, 2 (1), 7378.

55. Krivun, S.V.; Vozyiana, O.F.; Baranov, S. N., Zh. Obshch. Khim. 1972, 42 298-302; Chem. Abstr. 1972, 77, 34224-34227

TOC

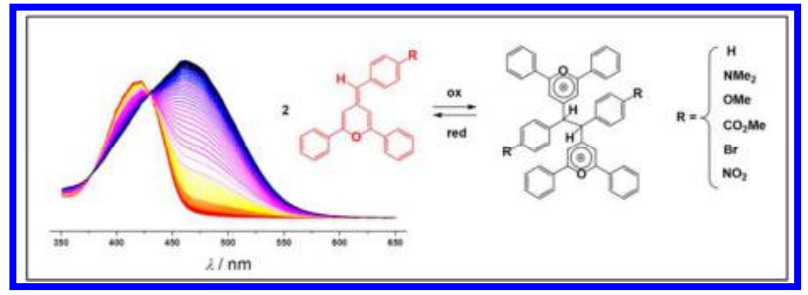

